\title{
DUST PARTICLE DEPOSITION QUALITY ASSESSMENT IN RURAL AREAS LOCATED NOT FAR FROM A CONGESTED HIGHWAY AND SEVERAL SEBKHAS: CASE OF MONASTIR REGION, EASTERN TUNISIA
}

\author{
Iness CHABBI, Moez BAHLOUL, Rim DAMMAK, Chafai AZRI* \\ Université de Sfax, Faculté des Sciences de Sfax, Unité de recherche "Étude et Gestion des Environnements Côtiers \\ et Urbains", BP 1171, 3000 Sfax, Tunisia
}

Received 02 February 2017; accepted 07 September 2017

\begin{abstract}
In order to better understand the processes of removing atmospheric particles to the surface, dry particle deposition in Monastir region (eastern Tunisia) has been studied. As a first step, a biweekly monitoring of the particulate deposits was carried out in 26 sites from January to August, 2012. Secondly, two particular sites were investigated from October, 2014 to August, 2015. A very high fluctuation in those particle fluxes, ranging from 0.560 to $2.210 \mathrm{~g} / \mathrm{m}^{2} / 14$ days, was clearly observed. The spatial distribution of particulate deposits shows a growing trend from rural to urban (coastal) areas depending on nearby sources (brickyards and clay quarries, road traffic and sebkhas) and meteorological factors (including precipitation and wind speed). The combined geochemical-statistical study of the particulate deposits elementary fluxes $\left(\mathrm{Cl}^{-}, \mathrm{Na}^{+}, \mathrm{K}^{+}, \mathrm{Ca}^{++}, \mathrm{Fe}^{(2,3)+}, \mathrm{Cd}, \mathrm{Pb}, \mathrm{Zn}, \mathrm{Ni}, \mathrm{Mn}\right.$ and $\left.\mathrm{Cu}\right)$ at the two observed rural and urban sites show a non-negligible impact of the anthropogenic component attributed to metals $(\mathrm{Pb}, \mathrm{Mn}, \mathrm{Zn}$, and $\mathrm{Cu}$ ). It is linked to the simultaneous effect of the urban (mainly road) activities in the Eastern part of the region and the intense fluidity of the motorway and railway in its Western part. The importance of the chlorine contributions of the terrigenous circulation has been attributed to the effect of sebkhas. The phenomenon of dust resuspension in agricultural areas, clay storage near brickyards and unbuilt sites has also been highlighted. The lowest biweekly elementary fluxes are probably due to the effect of rainfall periods which causes atmospheric whash-out.
\end{abstract}

Keywords: Monastir (Tunisia), particulate deposits, anthropogenic sources, sebkhas, meteorology, chemometric approaches.

\section{Introduction}

Atmospheric particles are complex mixtures of contributions from natural emission (marine, terrigenous) and anthropogenic sources (Seinfeld \& Pandis, 1998; Azri, Maalej, \& Medhioub, 2000; Allen, Nemitz, Shi, Harrison, \& Greenwood, 2001; Muhammad, I. K., Muhammad, I., Mubashir, \& Ammad, 2017). The marine source is responsible for the entrainment into the air of liquid bubbles rich in soluble elements $\left(\mathrm{Ca}^{++}, \mathrm{Mg}^{++}, \mathrm{Na}^{+}, \mathrm{K}^{+}, \mathrm{Cl}^{-}, \mathrm{SO}_{4}^{--}\right.$, etc. $)$, (Niemiet et al., 2005; Lu, Shao, Wu, \& Jiao, 2006; Bahloul et al., 2015a). The terrigenous source brings about crustal elements from soil erosion (Kubilay \& Saydam, 1995; Guerzoni et al., 1999), which mainly involve metal oxides $\left(\mathrm{Fe}_{2} \mathrm{O}_{3}\right)$, aluminosilicates $\left(\mathrm{SiO}_{2}, \mathrm{Al}_{2} \mathrm{O}_{3}\right)$ Clays, calcium sulfate $\left(\mathrm{CaSO}_{4}\right)$ and sodium chloride $(\mathrm{NaCl})$. Their presence in the atmosphere depends on their chemical form, the soil nature and the wind strength. The anthropogenic source mainly consists of elements resulting from man's socio-economic activities (industries, road traffic, waste incineration...). Two types of anthropogenic sources can be distinguished. On the one hand, the activities that directly emit pollutants into the atmosphere, such as tires and brake pads abrasion or cement plants. On the other hand, the particles derived from the gas/particles conversion process which represent most of the anthropogenic aerosols (Geraldine, Maul, Ferard, Carrot, \& Ayrault, 2004; Borghezi, Vione, Maurino, \& Minero, 2005; Azri, Chaabane, Abida, \& Medhioub, 2010). They are generally formed by metals, sulfur and nitrogen. The atmospheric particles can mak damage not only on human health (Rodriguez, Querol, Alastuey, Kallos, \& Kakaliagou, 2001; Chung, Kim, Park, Jugder, \& Tao, 2005) but also on the environments at different levels (Azri et al., 2000; Bond et al., 2004; Cao, Yang, Lu, \& Zhang, 2011; Ediagbonya, Ukpebor, Okiemien, \& Okungbowa, 2013; Shokr et al., 2016). The particles are polydispersed and heterogeneous.

${ }^{*}$ Corresponding author. E-mail: chafaiazri@yahoo.fr 
They are unstable and highly variable in time and space. The particle composition is in fact continuously modified by physico-chemical processes of transformation and elimination.

Dry deposition is one of the processes for removing atmospheric particles. The geochemical behaviour of particulate atmospheric deposition depends on the emission sources (natural and anthropogenic) as well as the local and regional or even synoptic meteorology (wind, cyclonic or anticyclone situations, precipitation, etc.) (Azri, Chaabane, \& Medhioub, 2009a; Bahloul et al., 2015b). It also depends on the physicochemical transformations to which the particles are subjected during their atmospheric transport and the characteristics of the receiving environments (Shahin, Lu, Yi, Paode, \& Holsen, 2000; Cindoruk \& Tasdemir, 2007). This dry atmospheric deposition might be particularly important near urban and industrial areas than rural ones (Fang \& Wu, 1999; Shahin et al., 2000).

This study examines the spatial and temporal evolution of dry particulate matter fluxes in agricultural lands located not far from highly frequented highway and railway and surrounded by sebkhas (Monastir case Region, Tunisia).

\section{Climatic characteristics of Monastir region}

The Monastir region, subject of our study, is located in the Tunisian Sahel (latitude $35^{\circ} 47$ 'N , longitude 10 $0^{\circ} 0^{\prime}$ E) (Figure 1). It is bordered on by the governorate of Sousse to the North and West, the governorate of Mahdia to the South and the Mediterranean Sea to the East (Figure 1). It lies over an area of $1019 \mathrm{~km}^{2}$ and located in the center of the large olive grove of the Sahel. The lands of the region are enriched with metal oxides $\left(\mathrm{Fe}_{2} \mathrm{O}_{3}\right)$, aluminosilicates $\left(\mathrm{SiO}_{2}, \mathrm{Al}_{2} \mathrm{O}_{3}\right)$ Clays and calcium carbonate $\left(\mathrm{CaCO}_{3}\right)$ (Tagorti, Essefi, Touir, Guellala, \& Yaich, 2013). It is surrounded by three sebkhas (Sidi El Hani, $\approx 370 \mathrm{~km}^{2}$, Moknine, $\approx 50 \mathrm{~km}^{2}$ and Sahline $\approx 26 \mathrm{~km}^{2}$ ). These are endoreic depressions $(\approx 0.4 \mathrm{~m}$ depth) containing saline water with high concentrations of $\mathrm{Na}^{+}$and $\mathrm{Cl}^{-}$. The water salinity is equal to $264 \mathrm{~g} / \mathrm{l}$ (Tagorti et al., 2010). In addition to its agricultural activity, particularly olive cultivation, the region is characterized, by the availability of clay deposits exploited for the manufacture of red building products (tiles, bricks, slabs). Actually, eight fully operational brickyards occupy the central part of this region today, (Figure 1). Their total annual brick production capacity is 4410000 tons. Heavy fuel (highly-viscous fossil fuel) and natural gas are used to dry and bake the bricks. The region's westearn part is proximate to a busy railway and motorway $(\approx 10 \mathrm{~km})$ connecting the southern regions to the northern one of Tunisia.

Monastir is characterized by a relatively mild Mediterranean climate in its eastern part and a dry and arid climate in its western part. Air temperatures varied between 8 and $17{ }^{\circ} \mathrm{C}$ in winter and 25 and $29^{\circ} \mathrm{C}$ in summer (Tagorti et al., 2013). The average annual rainfall is 270 and $400 \mathrm{~mm}$ in the western and eastern parts, respectively.

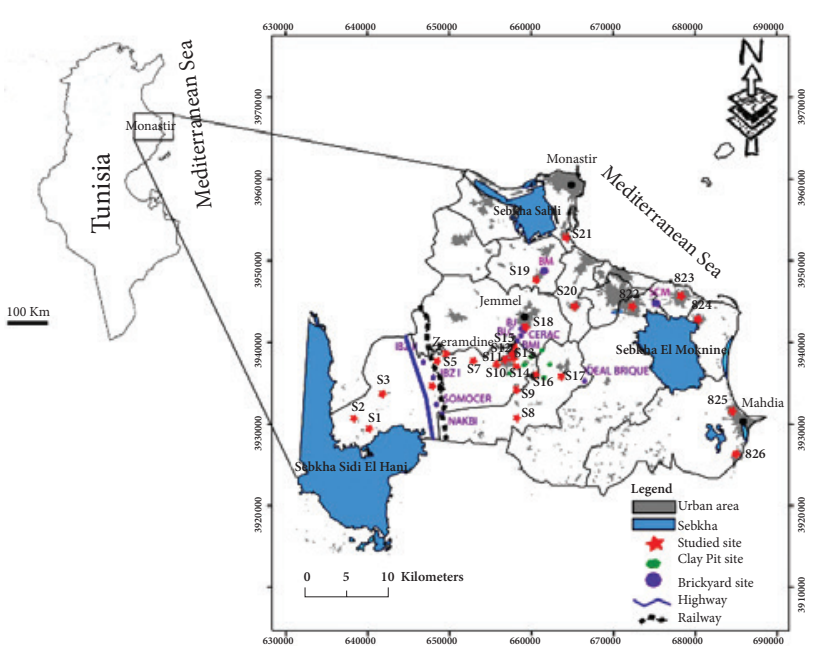

Figure 1. Map of the study area and sampling location in Monastir region, Tunisia

The monthly average of relative humidity varies between 69 and $75 \%$. The winds blow from all sectors, with varying frequencies. The prevalent winds are mainly from the eastern sector with average speeds around $4 \mathrm{~m} / \mathrm{s}$. The Saharan winds (Sirocco) threaten the whole region, especially during the summer season. These winds accentuate the evaporation phenomenon when it is accompanied with high temperatures above $40^{\circ} \mathrm{C}$.

Regarding to the urban planning over the region, the citizens distribution shows a high popular density in the eastern coastal part characterized by two touristic cities (Monastir and Mahdia) as well as marked by a small to medium density of population at other communities of the region (not exceeding 31000 inhabitants).

\section{Materials and methods}

The spatial and temporal variation of the particulate deposits fluxes has been studied in 26 collection sites (Urban/periurban/rural, S1 to S26) in the Monastir region (Figure 1). The study was achieved over two seperate periods: the first covered the period going from January to August 2012 while the second started in October 2014 and ended in August 2015. This second period was devoted to a further study focusing particularly on the quantitative and qualitative aspects of the particulate deposits harvested at two particular sites namely S14 and S23 receiving the highest average deposit fluxes.

The sampling procedure was carried out according to the NF standard 43-007, 2008, using DIEM plates. "Air Quality-Ambient Air-Determination of the Mass of Dry Atmospheric Depositions-Sampling on Deposit PlatesPreparation and Treatment" clearly described the plates placement, coated with petroleum jelly, to analyze and subsequently treat the collected dust fall samples. This method was detailed in several studies such as those of (Orange \& Gac, 1990; Marx \& McGowan, 2005; Bahloul et al., 2015a; Dammak, Bahloul, Chabbi, \& Azri, 2016). 
Measurement campaigns were carried out covering the selected periods on a biweekly basis. The choice of this period sample (a biweekly basis) is based on preliminary studies in the region of Monastir (Chabbi, 2012) testifying that 14-day periods are far enough to get deposits which go with trace elements (heavy metals) easily exceed the adopted analytical apparatus detection thresholds. The fluxes of atmospheric particulate deposits were then expressed in $\mathrm{g} / \mathrm{m}^{2} / 14$ days. The meteorological data such as air temperature, humidity, atmospheric pressure, wind velocity and dominant wind direction were gathered from the meteorological station of "Monastir-Skanes" aeroport (ID: 60740 DTTM; latitude $35^{\circ} 40^{\prime} \mathrm{N}$ and longitude $10^{\circ} 45^{\prime} \mathrm{E}$; altitude: $10 \mathrm{~m}$ ), the nearest meteorological station to the sampling sites.

The soluble fraction $\left(\mathrm{Fe}^{(2 ; 3)+}=\mathrm{Fe}^{2+}+\mathrm{Fe}^{3+}, \mathrm{Ca}^{++}, \mathrm{Na}^{+}\right.$, $\mathrm{Cl}^{-}, \mathrm{K}^{+}$) of the obtained liquid after filtration was acidified to $\mathrm{pH}<2$ with $\mathrm{HNO}_{3}$ and were analyzed by an Ion chromatography system (Compact IC Flex Metrohm). The analysis of the metals ( $\mathrm{Cd}, \mathrm{Pb}, \mathrm{Zn}, \mathrm{Ni}, \mathrm{Mn}$ and $\mathrm{Cu}$ ) of insoluble fraction trapped in the filter were analyzed by atomic absorption spectroscopy AAS with the air-acetylene flame (Analytik Jena model ZEEnit 700PC). The samples were digested with in a mixture of $\mathrm{HNO}_{3}+\mathrm{HF}$ according to the US EPA method 3050B (US EPA, 1999). The detection limits (mg/l) were 0.015 for $\mathrm{Cd}, 0.01$ for $\mathrm{Pb}, 0.002$ for $\mathrm{Zn}, 0.001$ for $\mathrm{Ni}$, for 0.001 for $\mathrm{Mn}, 0.004$ for $\mathrm{Cu}$ and 0.044 for $\mathrm{Fe}, 0.024$ for $\mathrm{Ca}, 0.015$ for $\mathrm{Na}, 0.010$ for $\mathrm{Cl}$ and 0.001 for $\mathrm{K}$.

\section{Results and discussion}

\subsection{Spatial and temporal variations of atmospheric particulate deposits over Monastir region}

The study of the particulate deposits fluxes in the Monastir region during the January-August 2012 period shows a very noticeable spatial variability (Table 1 ). The average deposition fluxes range between 0.560 and $2.210 \mathrm{~g} / \mathrm{m}^{2} / 14$ days. The recorded deposit fluxes seem to be very different when compared to other Tunisian sites and those of various regions of the world, (Table 2). This difference can be explained by such factors as the variety of the sampling techniques, the characteristics of the study areas (rural, peri-urban, urban) and sampling periods. Referring to the guide values of the AFNOR standards (set at $14 \mathrm{~g} / \mathrm{m}^{2} / 14$ days) and TA-LUFT (German air law set at $4.9 \mathrm{~g} / \mathrm{m}^{2} / 14$ days), the recorded average biweekly fluxes are noticed to be well below the limit values of these two standards.

Table 1. Variation of the fluxes ( $\mathrm{g} / \mathrm{m}^{2} / 14$ days) of dry particulate deposits during the first period (from January to August, 2012)

\begin{tabular}{|c|c|c|c|c|c|c|c|c|c|c|c|c|c|c|c|c|c|c|}
\hline $\begin{array}{c}\text { Campaigns / } \\
\text { sites }\end{array}$ & $\mathrm{C} 1$ & C2 & C3 & $\mathrm{C} 4$ & C5 & C6 & C7 & C8 & C9 & $\mathrm{C} 10$ & $\mathrm{C} 11$ & $\mathrm{C} 12$ & $\mathrm{C} 13$ & $\mathrm{C} 14$ & $\mathrm{C} 15$ & C16 & $\mathrm{C} 17$ & \begin{tabular}{|l|} 
Average fluxes \\
$\left(\mathrm{g} / \mathrm{m}^{2} / 14\right.$ days $)$
\end{tabular} \\
\hline S1 & 76 & 366 & 321 & 214 & 0.698 & 433 & 291 & 385 & 1.07 & 1.755 & 0.732 & 1.382 & 1.472 & 1.561 & 1.3 & 1.997 & 0.256 & 940 \\
\hline S2 & 458 & 356 & 342 & 0.601 & 0.769 & 0.593 & 0.95 & 0.715 & 1.401 & 1.6 & 1.564 & 1.122 & 1.307 & 1.515 & 1.578 & 0.716 & 0.909 & 970 \\
\hline S3 & 172 & 376 & 581 & 845 & 0.783 & 0.285 & .438 & 1.51 & 1.583 & 1.406 & 1.512 & 1.156 & 1.202 & 1.429 & 1.356 & 0.732 & 0.325 & 980 \\
\hline S4 & 168 & 493 & 483 & 1.618 & 0.598 & 456 & 476 & 214 & 1.49 & 1.306 & 1.967 & 1.218 & 0.103 & 1.365 & 1.821 & 0.651 & 0.319 & 930 \\
\hline S5 & . & . & 385 & 168 & 1.254 & 627 & 966 & 172 & 1.131 & 0.348 & 1.339 & 1.179 & 1.023 & 0.627 & 0.14 & 0.569 & 0.313 & 820 \\
\hline S6 & - & 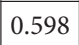 & 111 & 0.92 & .265 & 561 & 111 & 101 & 0.348 & 1.342 & 0.598 & 0.826 & 0.741 & 0.598 & 0.855 & 0.513 & 0.301 & . \\
\hline $\mathrm{S}$ & 131 & 0.148 & 1 & 225 & 8 & 66 & 3 & 1.207 & 1 & 1 & 14 & 22 & 7 & 0.94 & 387 & 1.385 & 0.277 & 00 \\
\hline$S$ & 094 & .103 & 162 & 82 & 182 & 0.1 & 31 & 1.283 & 0. & 88 & 77 & 51 & 37 & 75 & 85 & 2.256 & 0.229 & .070 \\
\hline SS & 0.174 & 131 & 197 & 729 & 0.553 & 199 & 641 & .088 & 1.256 & 1.023 & 1.179 & 1.077 & 0.168 & 0.858 & 0.741 & 0.262 & 0.231 & 560 \\
\hline $\mathrm{S} 10$ & 707 & 843 & 515 & 1.959 & 0.434 & 1.037 & 1.786 & 1.801 & 0.624 & 0.484 & 1.181 & 0.698 & 0.816 & 1.252 & 0.698 & 0.299 & 0.439 & 1.030 \\
\hline S11 & 801 & 081 & 0.666 & 0.189 & 0.468 & 0.883 & 0.937 & 1.613 & 0.602 & 1.473 & 1.202 & 1.405 & 1.464 & 1.847 & 1.656 & 0.336 & 0.646 & 1.020 \\
\hline $\mathrm{S} 12$ & 0.895 & 0.319 & 1.818 & 2.246 & 0.131 & 0.829 & 0.937 & 0.399 & 1.248 & 1.39 & 0.442 & 1.194 & 1.373 & 0.929 & 1.242 & \begin{tabular}{|l|l|}
0.649 \\
\end{tabular} & 1.062 & 1.010 \\
\hline $\mathrm{S} 13$ & 0.489 & 0.895 & \begin{tabular}{|l}
0.909 \\
\end{tabular} & 1.501 & 0.682 & 1.65 & 1.829 & 0.937 & 0.989 & 1.248 & 1.339 & 1.442 & 1.194 & 0.373 & 0.929 & \begin{tabular}{|l|}
0.962 \\
\end{tabular} & 0.894 & 1.070 \\
\hline S14 & 1.279 & 1.976 & 0.711 & 1.809 & 0.719 & 1.453 & 0.909 & 0.550 & 1.595 & 1.988 & 1.097 & 1.529 & 1.803 & 1.464 & 1.987 & 1.897 & 1.557 & 1.430 \\
\hline S15 & 1.167 & 291 & 1.1 & 1.57 & 1.541 & 1.259 & 0.427 & 0.855 & 0.923 & 1.342 & 0.989 & 0.949 & 0.929 & 1.786 & 0.731 & 1.783 & 1.308 & 1.170 \\
\hline S16 & . & 439 & 1.667 & 2.222 & 0.399 & 0.305 & 1.957 & .105 & 1.607 & 0.157 & 2.06 & 0.558 & 0.655 & 0.382 & 2.479 & 0.724 & 1.177 & 1.290 \\
\hline S17 & 329 & 912 & 1.114 & 1.812 & 0.148 & 0.912 & 1.997 & 994 & 2.212 & 0.516 & 1.798 & 1.772 & 2.137 & 2.145 & 0.912 & 2.103 & 1.046 & 1.430 \\
\hline S18 & (.0.7) & 0.504 & 1.282 & 0.718 & 0.700 & 1.302 & 1.672 & 2.701 & 0.818 & 2.71 & 1.197 & 1.812 & 2.308 & 0.53 & 0.497 & 2.689 & 0.930 & 1.000 \\
\hline S & 0.397 & 1 & 7 & 4 & 1 & 9 & 5 & 1.066 & 1.85 & 5 & 8 & 5 & 7 & 8 & 41 & 58 & 8 & 1.200 \\
\hline $\mathrm{S} 2$ & 0.415 & 0 & 1.43 & 39 & 0. & 32 & 53 & 96 & 3.614 & 937 & 0.291 & 72 & 11 & 87 & 46 & 1.954 & 584 & 1.340 \\
\hline S2. & 0.508 & 1.872 & 1.333 & 1.65 & 1.496 & 3.074 & 3.393 & 3.373 & 0.824 & 0.952 & 0.599 & 0.471 & 1.288 & 1.114 & 1.439 & \begin{tabular}{|l|l|}
1.768 \\
\end{tabular} & 0.627 & .520 \\
\hline S22 & 0.523 & 2.906 & 0.98 & 3.561 & 2.45 & 3.789 & 1.709 & 0.977 & 0.963 & 1.453 & 0.94 & 1.527 & 0.956 & 0.513 & 1.833 & 1.581 & 0.57 & 1.600 \\
\hline S23 & 0.666 & 3.436 & 0.627 & 2.67 & 1.453 & 1.105 & 3.393 & 3.026 & 3.282 & 1.587 & 0.379 & 0.481 & 2.097 & 3.681 & 4.062 & 2.208 & 3.456 & 2.210 \\
\hline S24 & 1.147 & 1.953 & 1.688 & 2.51 & 1.446 & 1.272 & 1.23 & 1.102 & 1.023 & 2.054 & 0.439 & 1.145 & 1.786 & 3.173 & 2.409 & 1.527 & 1.928 & 1.640 \\
\hline S25 & 1.628 & 0.47 & 2.75 & 2.351 & 1.439 & 1.439 & 1.496 & 1.411 & 2.009 & 2.522 & 0.499 & 1.809 & 1.476 & 2.664 & 0.755 & \begin{tabular}{|l|l|} 
\\
\end{tabular} & 0.4 & 1.530 \\
\hline S26 & 2.928 & 0.677 & 1.304 & 2.574 & 1.356 & 1.434 & 1.422 & 1.504 & 1.304 & 2.298 & 0.449 & 2.857 & 1.761 & 1.264 & 1.015 & \begin{tabular}{|l|l|}
0.766 \\
\end{tabular} & 0.622 & 1.500 \\
\hline
\end{tabular}


Table 2. Fluxes of particulate deposits ( $\mathrm{g} / \mathrm{m}^{2} / 14$ days) measured at different conditions from several areas over the world

\begin{tabular}{|c|c|c|c|c|}
\hline Study area & $\begin{array}{c}\text { Average of dry } \\
\text { particulate deposits } \\
\text { measured at different } \\
\text { conditions } \\
\left(\mathrm{g} / \mathrm{m}^{2} / 14 \text { days }\right)\end{array}$ & & Study Period & References \\
\hline $\begin{array}{l}\text { Monastir region (Eastern } \\
\text { Tunisia) }\end{array}$ & $0.56 / 2.21$ & Rural/urban & $\begin{array}{l}\text { From January to August } \\
2012\end{array}$ & This work \\
\hline \multirow[t]{2}{*}{ Sfax city (Southern Tunisia) } & 5.56 & Urban & \multirow{2}{*}{$\begin{array}{l}\text { From April to November } \\
2014\end{array}$} & \multirow[t]{2}{*}{ Dammak et al. (20016) } \\
\hline & 2.49 & Suburban & & \\
\hline Southern urban of Sfax (Tunisia) & 3.5 & Urban (coastal) & $\begin{array}{l}\text { From April to November } \\
2012\end{array}$ & Bahloul et al. (2015a) \\
\hline Vegoritis (western Greece) & 1.54 & Rural (coastal) & \multirow{3}{*}{$\begin{array}{l}\text { From January to October } \\
2001\end{array}$} & \multirow[t]{3}{*}{ Terzi and Samara (2005) } \\
\hline Petrana(western Greece) & 1.582 & Rural & & \\
\hline Kozani (western Greece) & 2.66 & Urban & & \\
\hline $\begin{array}{l}\text { Mallorca (Balearic Islands, } \\
\text { Spain) }\end{array}$ & 0.238 & Rural & $\begin{array}{l}\text { From September } 2010 \text { to } \\
\text { August } 2012\end{array}$ & Cerro et al. (2014) \\
\hline $\begin{array}{l}\text { Tafira, Gran Canaria, Canary } \\
\text { Islands (Spain) }\end{array}$ & 0.35 & Rural & $\begin{array}{l}\text { From February } 2009 \text { to } \\
\text { February } 2012\end{array}$ & López-García et al. (2013) \\
\hline $\begin{array}{l}\text { Montiers-sur-Saulx } \\
\text { (Northeastern of France) }\end{array}$ & 0.066 & Rural & $\begin{array}{l}\text { From September } 2011 \text { to } \\
\text { March } 2012\end{array}$ & $\begin{array}{l}\text { Lequy, Calvaruso, Conil, } \\
\text { \& Turpault (2014) }\end{array}$ \\
\hline Lyon (France) & 0.85 & Rural & 1993-1994 & Gabet (1999) \\
\hline Costantine (Algeria) & 15.471 & Urban & $2004-2006$ & Serghani (2009) \\
\hline Dakar (Sénégal) & 7.92 & Urban & $1984-1988$ & Orange and Gac (1990) \\
\hline Mazowieckie Province (pologne) & 3.38 & Urban & $1995-1998$ & Królak (2000) \\
\hline Jersey City((New York, USA ) & 1.372 & $\begin{array}{l}\text { urban/ } \\
\text { industrial }\end{array}$ & $\begin{array}{l}\text { From August } 2001 \text { to } \\
\text { August } 2002\end{array}$ & Yi et al. (2006) \\
\hline $\begin{array}{l}\text { Taichung Harbor (western side } \\
\text { of central, Taiwan) }\end{array}$ & 0.823 & Coastal & \multirow[t]{2}{*}{$\begin{array}{l}\text { From March } 2004 \text { to } \\
\text { January } 2005\end{array}$} & \multirow[t]{2}{*}{$\begin{array}{l}\text { Fang, Wu, Wen, Huang, } \\
\text { \& Rau (2006) }\end{array}$} \\
\hline Wuchi (Taiwan) & 0.728 & Urban (traffic) & & \\
\hline Yangpyoung (Korea) & 0.448 & Rural & $\begin{array}{l}\text { From February to May } \\
2000\end{array}$ & Bae, Yi, \& Kim (2002) \\
\hline $\begin{array}{l}\text { Gaomei wetland (western } \\
\text { Taïwan) }\end{array}$ & 13.18 & Coastal & \multirow[t]{2}{*}{$\begin{array}{l}\text { From October to } \\
\text { December } 2001\end{array}$} & \multirow[t]{2}{*}{ Yang et al. (2004) } \\
\hline $\begin{array}{l}\text { Chaoyang University (Taichun, } \\
\text { Taïwan) }\end{array}$ & 16.32 & Suburban & & \\
\hline
\end{tabular}

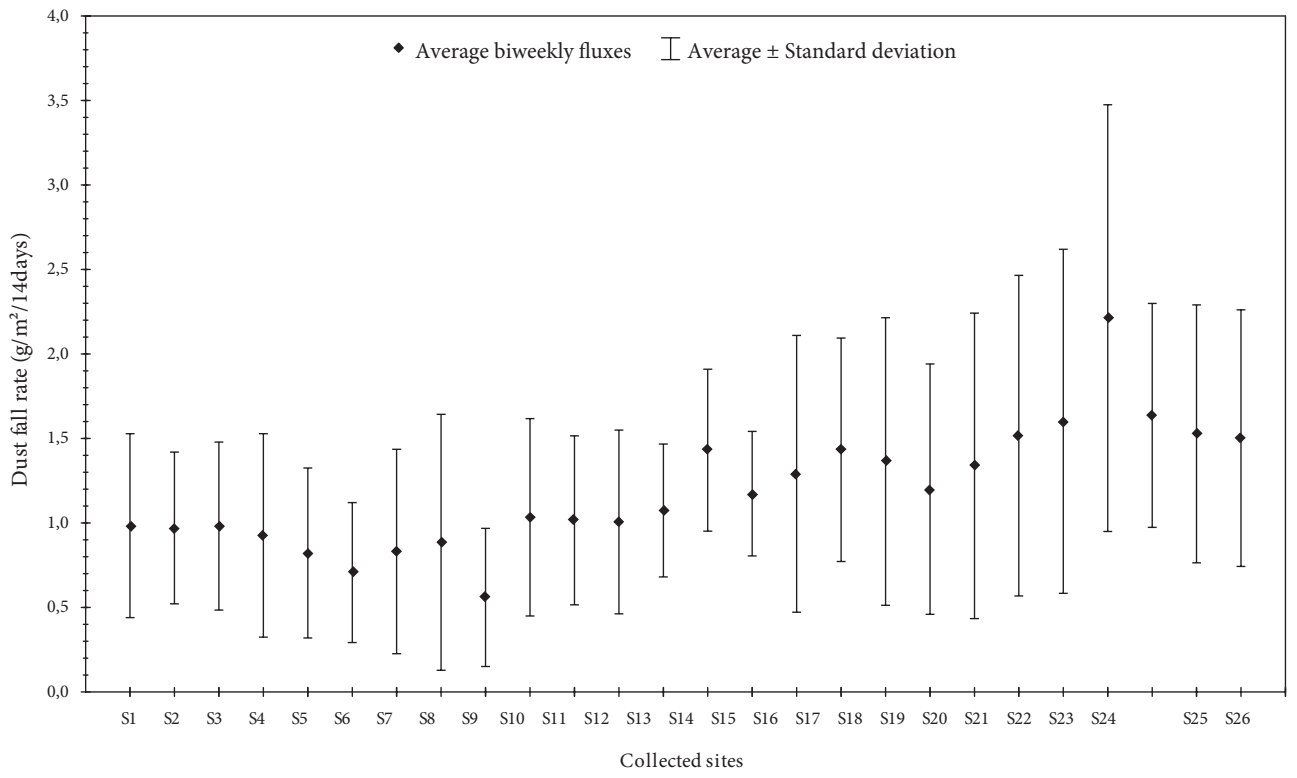

Figure 2. Intersite distribution of biweekly dust fall rate above Monastir region, Tunisia 


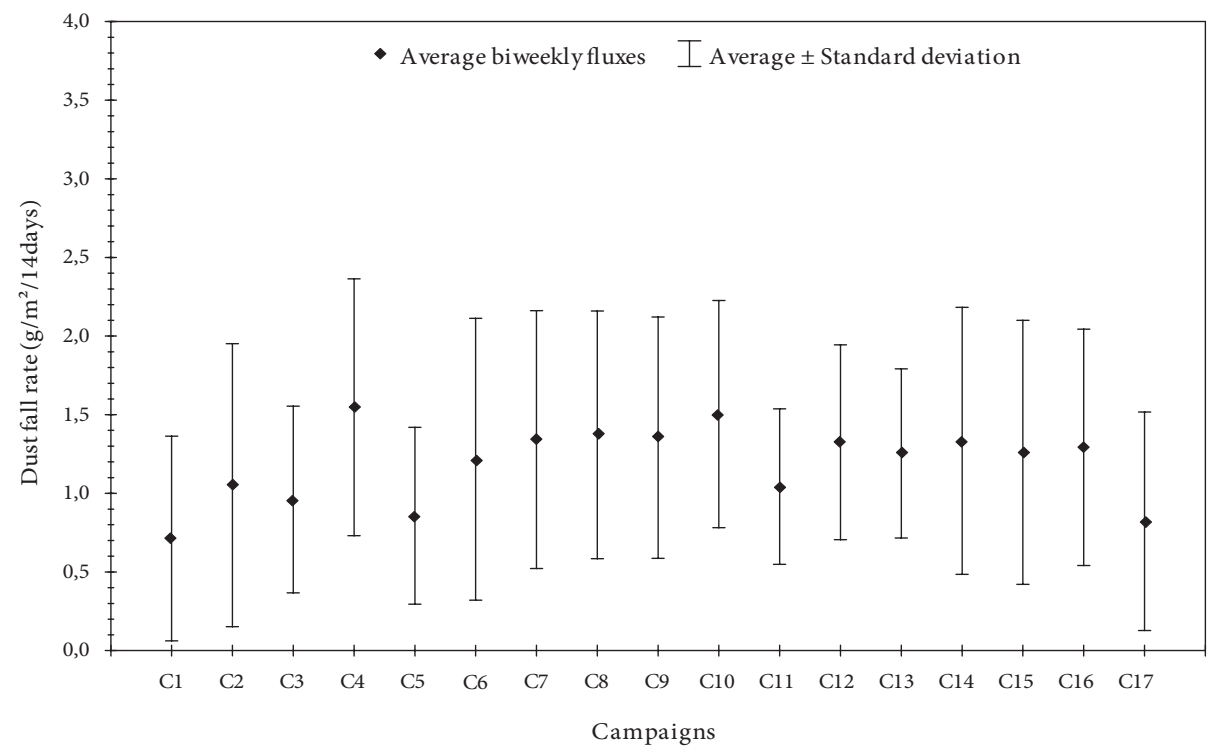

Figure 3. Temporal variations of biweekly dust fall rate

The spatial evolution of the particulate deposits fluxes shows very distinct patterns with varying amplitudes (Figure 2). The average trend of deposit fluxes shows an increasing trend going from rural to urban (coastal) sites. Based on their behavior (i.e., trends and amplitudes), spatial distribution of particulate fallout fluxes can be classified into three main groups (Figure 2):

- A first group covering $35 \%$ of the studied sites (S1 to S9) recording the lowest deposit fluxes characterized by mean values close to $1 \mathrm{~g} / \mathrm{m}^{2} / 14$ days. The representative sites in this area are rural, located in the western part of the region;

- A second group extending over $42 \%$ of the studied sites (S10 to S20) with medium average fluxes fluctuating between 1 and $1.5 \mathrm{~g} / \mathrm{m}^{2} / 14$ days. It lies in the central area of the study region, close to brickyards and clay quarries. In this area, S14 records the highest average deposit flow;

- A third group covering 23\% of the studied sites (S21 to S26) with the highest average fluxes ranging between 1.5 and $2.21 \mathrm{~g} / \mathrm{m}^{2} / 14$ days. The representative sites of this area are urban, located on the coastal zone (East) of the region. It should be noted that the highest average biweekly flow in this zone, is recorded at site S23.

Temporal variation of particulate deposit fluxes demonstrated an average value of 0.710 and $1.560 \mathrm{~g} / \mathrm{m}^{2} / 14$ days, showing large fluctuations (Figure 3) within the same site and between sites. These fluctuations can be attributed to the combined effect of both neighboring sources and the airflow properties which have been governed by meteorological conditions for a long time.

The spatial distribution of the mean particulate deposition fluxes highlights the importance of the peaks at the sites S14 and S23. The first, (S14), is located near brick kilns and clay quarries (Figure 1). Referring to the wind rose (Figure 4), this site was frequently exposed to brick plumes (24\% out of the total number of observations). Moreover, because of its proximity to the clay quarries (about $20 \mathrm{~m}$ ), this site seems to be also threatened by the surge of a mechanical dust emanating from both clay storage and transport. As for the site S23, its locality in an urban area could testify the obvious effect of the road traffic in this location, in the absence of significant industrial sources. For a better understanding of the particulate deposit specificities at the two aforementioned sites, a further study focusing on their quantitative and qualitative aspects was conducted during a second period (from October 2014 to August 2015). The main results of this study are detailed in the following paragraphs.

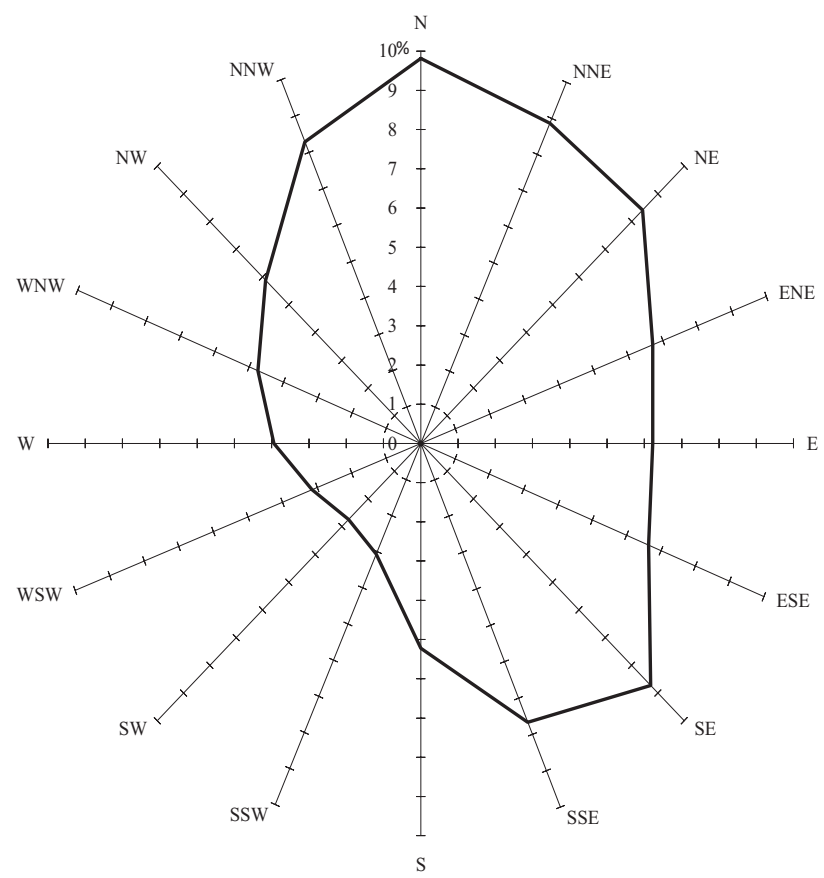

Figure 4. Wind distributions (\%) during the first study period (From January to August, 2012) 


\subsection{Water-soluble/insoluble components in atmospheric particulate deposits at the two particular sites (S14 and S23)}

The main reason for the particulate deposits quantitative study of the S14 and S23 sites is their high average fluxes recorded above these sites. Therefore, they were selected for the soluble $\left(\mathrm{Fe}^{(2 ; 3)+}, \mathrm{Ca}^{++}, \mathrm{Na}^{+}, \mathrm{K}^{+}, \mathrm{Cl}^{-}\right)$and insoluble $(\mathrm{Pb}, \mathrm{Cu}, \mathrm{Cd}, \mathrm{Zn}, \mathrm{Mn})$ phases investigation of the particulate deposits. This specific study covered a second period from October 2014 to August 2015. The responsible sources for the enrichment of the sedimentable particles and their rates of contribution have been detailed. A statistical study based on simple linear regressions and a factorial analysis of the correspondences was adopted.

\subsubsection{Temporal evolution of particulate deposits constituents}

The biweekly fluxes of the main particulate deposits $\left(\mathrm{Fe}^{(2 ; 3)+}, \mathrm{Ca}^{++}, \mathrm{Na}^{+}, \mathrm{K}^{+}, \mathrm{Cl}^{-}, \mathrm{Pb}, \mathrm{Cu}, \mathrm{Cd}, \mathrm{Zn}, \mathrm{Ni}\right.$ et $\left.\mathrm{Mn}\right)$ at the two selected sites (S14 and S23) show considerable variability (Tables 3 and 4 ). These fluxes vary between 0.017 and $2.006 \mathrm{~g} / \mathrm{m}^{2} / 14$ days at (S14), the agricultural site representative of the central sector, while they range between 0.019 and $1.863 \mathrm{~g} / \mathrm{m}^{2} / 14$ days at S23 the coastal urban site.

Furthermore, the S14 average elementary fluxes of the soluble phase $\left(\mathrm{Fe}^{(2 ; 3)+}, \mathrm{Ca}^{++}, \mathrm{Na}^{+}, \mathrm{K}^{+}, \mathrm{Cl}^{-}\right)$are ranked in the following descending order: $\mathrm{Ca}^{++}>\mathrm{Fe}^{(2 ; 3)+}>\mathrm{Cl}^{-}>\mathrm{Na}^{+}>\mathrm{K}^{+}$. As for those of S23, they are distinguished by a decreasing order of the type: $\mathrm{Cl}^{-}>\mathrm{Na}^{+}>\mathrm{Ca}^{++}>\mathrm{Fe}^{(2 ; 3)+}>\mathrm{K}^{+}$.

Table 3. Dry deposition fluxes of analyzed constituents $\left(\mathrm{g} / \mathrm{m}^{2} / 14\right.$ days) over S14 during the second period (from October, 2014 to August, 2015)

\begin{tabular}{|c|c|c|c|c|c|c|c|c|c|c|c|}
\hline Campaigns & $\mathrm{Ca}^{++}$ & $\mathrm{Fe}^{(2 ; 3)+}$ & $\mathrm{K}^{+}$ & $\mathrm{Cl}^{-}$ & $\mathrm{Na}^{+}$ & $\mathrm{Zn}$ & $\mathrm{Pb}$ & $\mathrm{Cd}$ & $\mathrm{Cu}$ & $\mathrm{Ni}$ & $\mathrm{Mn}$ \\
\hline $\mathrm{C} 1$ & 0.124 & 0.111 & 0.009 & 0.098 & 0.04 & 0.011 & 0.012 & 0.008 & 0.001 & 0.002 & 0.009 \\
\hline $\mathrm{C} 2$ & 0.018 & 0.016 & 0.002 & 0.029 & 0.009 & 0.001 & 0.001 & 0.001 & 0.001 & 0.001 & 0.001 \\
\hline $\mathrm{C} 3$ & 0.103 & 0.092 & 0.020 & 0.124 & 0.056 & 0.020 & 0.005 & 0.002 & 0.003 & 0.008 & 0.007 \\
\hline $\mathrm{C} 4$ & 0.203 & 0.181 & 0.001 & 0.108 & 0.049 & 0.012 & 0.020 & 0.002 & 0.001 & 0.010 & 0.015 \\
\hline C5 & 0.769 & 0.684 & 0.110 & 0.014 & 0.001 & 0.026 & 0.077 & 0.042 & 0.011 & 0.066 & 0.055 \\
\hline C6 & 0.060 & 0.053 & 0.008 & 0.001 & 0.001 & 0.001 & 0.001 & 0.001 & 0.001 & 0.001 & 0.004 \\
\hline C7 & 0.124 & 0.111 & 0.001 & 0.151 & 0.099 & 0.018 & 0.012 & 0.001 & 0.001 & 0.001 & 0.009 \\
\hline C8 & 0.750 & 0.668 & 0.102 & 0.013 & 0.0056 & 0.110 & 0.102 & 0.031 & 0.089 & 0.083 & 0.053 \\
\hline C9 & 0.001 & 0.001 & 0.001 & 0.010 & 0.005 & 0.001 & 0.001 & 0.001 & 0.001 & 0.001 & 0.001 \\
\hline $\mathrm{C} 10$ & 0.009 & 0.008 & 0.001 & 0.001 & 0.001 & 0.001 & 0.001 & 0.001 & 0.001 & 0.001 & 0.001 \\
\hline C11 & 0.078 & 0.070 & 0.001 & 0.174 & 0.102 & 0.006 & 0.054 & 0.001 & 0.001 & 0.009 & 0.006 \\
\hline C12 & 0.047 & 0.042 & 0.001 & 0.201 & 0.092 & 0.004 & 0.001 & 0.001 & 0.001 & 0.001 & 0.003 \\
\hline C13 & 0.667 & 0.603 & 0.023 & 0.010 & 0.005 & 0.088 & 0.088 & 0.007 & 0.021 & 0.080 & 0.048 \\
\hline C14 & 0.125 & 0.111 & 0.001 & 0.150 & 0.069 & 0.011 & 0.013 & 0.001 & 0.001 & 0.002 & 0.009 \\
\hline C15 & 0.537 & 0.505 & 0.003 & 0.031 & 0.014 & 0.046 & 0.057 & 0.006 & 0.011 & 0.065 & 0.040 \\
\hline C16 & 0.536 & 0.503 & 0.135 & 0.01 & 0.007 & 0.011 & 0.057 & 0.006 & 0.011 & 0.099 & 0.040 \\
\hline C17 & 0.091 & 0.111 & 0.001 & 0.098 & 0.04 & 0.008 & 0.009 & 0.001 & 0.001 & 0.006 & 0.007 \\
\hline C18 & 0.754 & 0.572 & 0.039 & 0.018 & 0.008 & 0.060 & 0.112 & 0.010 & 0.009 & 0.049 & 0.054 \\
\hline C19 & 0.793 & 0.784 & 0.004 & 0.009 & 0.001 & 0.0578 & 0.072 & 0.008 & 0.081 & 0.056 & 0.052 \\
\hline C20 & 0.542 & 0.482 & 0.003 & 0.047 & 0.022 & 0.042 & 0.054 & 0.006 & 0.001 & 0.009 & 0.039 \\
\hline C21 & 0.652 & 0.510 & 0.003 & 0.009 & 0.002 & 0.052 & 0.065 & 0.007 & 0.001 & 0.010 & 0.046 \\
\hline $\mathrm{C} 22$ & 0.762 & 0.678 & 0.004 & 0.001 & 0.001 & 0.061 & 0.076 & 0.008 & 0.001 & 0.012 & 0.054 \\
\hline Average & 0.352 & 0.313 & 0.022 & 0.060 & 0.029 & 0.029 & 0.040 & 0.007 & 0.011 & 0.026 & 0.025 \\
\hline Maximum & 0.793 & 0.784 & 0.135 & 0.201 & 0.102 & 0.110 & 0.112 & 0.042 & 0.089 & 0.099 & 0.055 \\
\hline Minimum & 0.001 & 0.001 & 0.001 & 0.001 & 0.001 & 0.001 & 0.001 & 0.001 & 0.001 & 0.001 & 0.001 \\
\hline $\begin{array}{l}\text { Standard } \\
\text { deviation }\end{array}$ & 0.313 & 0.278 & 0.040 & 0.065 & 0.03 & 0.031 & 0.038 & 0.010 & 0.025 & 0.033 & 0.022 \\
\hline
\end{tabular}


Table 4. Dry deposition fluxes of analyzed constituents ( $\mathrm{g} / \mathrm{m}^{2} / 14$ days) over S23 during the second period (from October, 2014 to August, 2015)

\begin{tabular}{|c|c|c|c|c|c|c|c|c|c|c|c|}
\hline Campaigns & $\mathrm{Ca}^{++}$ & $\mathrm{Fe}^{(2 ; 3)+}$ & $\mathrm{K}^{+}$ & $\mathrm{Cl}^{-}$ & $\mathrm{Na}^{+}$ & $\mathrm{Zn}$ & $\mathrm{Pb}$ & $\mathrm{Cd}$ & $\mathrm{Cu}$ & $\mathrm{Ni}$ & $\mathrm{Mn}$ \\
\hline $\mathrm{C} 1$ & 0.023 & 0.020 & 0.007 & 0.868 & 0.530 & 0.001 & 0.001 & 0.001 & 0.009 & 0.011 & 0.006 \\
\hline $\mathrm{C} 2$ & 0.315 & 0.189 & 0.032 & 0.150 & 0.019 & 0.006 & 0.032 & 0.007 & 0.130 & 0.017 & 0.061 \\
\hline C3 & 0.538 & 0.431 & 0.378 & 0.110 & 0.053 & 0.063 & 0.038 & 0.008 & 0.098 & 0.047 & 0.053 \\
\hline $\mathrm{C} 4$ & 0.432 & 0.390 & 0.099 & 0.124 & 0.097 & 0.042 & 0.016 & 0.010 & 0.018 & 0.038 & 0.026 \\
\hline $\mathrm{C} 5$ & 0.320 & 0.289 & 0.008 & 0.112 & 0.020 & 0.031 & 0.009 & 0.006 & 0.134 & 0.028 & 0.031 \\
\hline C6 & 0.10 & 0.091 & 0.002 & 0.091 & 0.012 & 0.019 & 0.001 & 0.001 & 0.068 & 0.005 & 0.002 \\
\hline C7 & 0.425 & 0.384 & 0.298 & 0.050 & 0.042 & 0.034 & 0.030 & 0.007 & 0.031 & 0.039 & 0.044 \\
\hline $\mathrm{C} 8$ & 0.449 & 0.305 & 0.378 & 0.047 & 0.031 & 0.022 & 0.017 & 0.004 & 0.031 & 0.022 & 0.032 \\
\hline C9 & 0.151 & 0.137 & 0.024 & 0.033 & 0.097 & 0.001 & 0.001 & 0.001 & 0.002 & 0.001 & 0.001 \\
\hline $\mathrm{C} 10$ & 0.114 & 0.103 & 0.036 & 0.030 & 0.060 & 0.010 & 0.004 & 0.002 & 0.078 & 0.013 & 0.011 \\
\hline $\mathrm{C} 11$ & 0.063 & 0.057 & 0.012 & 0.232 & 0.180 & 0.005 & 0.001 & 0.002 & 0.040 & 0.005 & 0.005 \\
\hline $\mathrm{C} 12$ & 0.013 & 0.003 & 0.001 & 0.001 & 0.001 & 0.001 & 0.001 & 0.001 & 0.002 & 0.001 & 0.001 \\
\hline C13 & 0.090 & 0.282 & 0.172 & 0.451 & 0.246 & 0.028 & 0.012 & 0.001 & 0.061 & 0.007 & 0.018 \\
\hline $\mathrm{C} 14$ & 0.057 & 0.052 & 0.064 & 0.665 & 0.420 & 0.005 & 0.006 & 0.001 & 0.035 & 0.004 & 0.005 \\
\hline C15 & 0.081 & 0.074 & 0.063 & 0.551 & 0.325 & 0.007 & 0.009 & 0.001 & 0.054 & 0.006 & 0.007 \\
\hline C16 & 0.033 & 0.031 & 0.016 & 0.761 & 0.530 & 0.002 & 0.002 & 0.001 & 0.017 & 0.002 & 0.002 \\
\hline $\mathrm{C} 17$ & 0.112 & 0.102 & 0.092 & 0.30 & 0.147 & 0.024 & 0.023 & 0.006 & 0.077 & 0.016 & 0.046 \\
\hline C18 & 0.111 & 0.101 & 0.229 & 0.448 & 0.136 & 0.010 & 0.010 & 0.001 & 0.076 & 0.006 & 0.010 \\
\hline C19 & 0.100 & 0.091 & 0.153 & 0.451 & 0.179 & 0.009 & 0.013 & 0.001 & 0.068 & 0.008 & 0.009 \\
\hline $\mathrm{C} 20$ & 0.089 & 0.081 & 0.123 & 0.553 & 0.380 & 0.008 & 0.009 & 0.001 & 0.059 & 0.007 & 0.008 \\
\hline $\mathrm{C} 21$ & 0.113 & 0.103 & 0.269 & 0.761 & 0.496 & 0.010 & 0.012 & 0.002 & 0.078 & 0.009 & 0.010 \\
\hline $\mathrm{C} 22$ & 0.142 & 0.119 & 0.353 & 0.334 & 0.220 & 0.018 & 0.015 & 0.002 & 0.099 & 0.012 & 0.013 \\
\hline Average & 0.176 & 0.156 & 0.128 & 0.326 & 0.192 & 0.016 & 0.012 & 0.003 & 0.058 & 0.014 & 0.018 \\
\hline Maximum & 0.538 & 0.431 & 0.378 & 0.868 & 0.530 & 0.063 & 0.038 & 0.010 & 0.134 & 0.047 & 0.061 \\
\hline Minimum & 0.013 & 0.003 & 0.001 & 0.001 & 0.001 & 0.001 & 0.001 & 0.001 & 0.002 & 0.001 & 0.001 \\
\hline $\begin{array}{l}\text { Standard } \\
\text { deviation }\end{array}$ & 0.158 & 0.129 & 0.132 & 0.276 & 0.178 & 0.016 & 0.011 & 0.003 & 0.038 & 0.013 & 0.018 \\
\hline
\end{tabular}

Similarly, the mean biweekly fluxes of metal deposits are relatively greater and with the following descending order: $\mathrm{Pb}>\mathrm{Zn}>\mathrm{Ni}>\mathrm{Mn}>\mathrm{Cu}>\mathrm{Cd}$ at $\mathrm{S} 14$. At S23, however, they are in a descending order of this type: $\mathrm{Cu}>\mathrm{Mn}>\mathrm{Zn}$ $>\mathrm{Ni}>\mathrm{Pb}>\mathrm{Cd}$.

The obtained orders for both soluble and insoluble phases are different for the two sites. This difference in order is mainly related to the positions occupied by the elements $\mathrm{Cl}, \mathrm{Na}, \mathrm{Mn}, \mathrm{Pb}$ and $\mathrm{Cu}$.

This change in fluxes order could be attributed to the influence of nearby sources and weather conditions. The importance of $\mathrm{Cl}$ and $\mathrm{Na}$ fluxes in the S23 deposits (coastal) site could possibly be attributed to the maritime influence. However, the Sahline, El Moknine and Sidi El Hani Sebkhas' impact hypothesis can not be excluded. These sebkhas are located in the Northern, Southeastern and Southwestern parts of the Monastir region. The importance of the $\mathrm{Pb}$ fluxes in the S14 deposits and $\mathrm{Cu}$ and $\mathrm{Mn}$ in the S23 deposits may reflect the distinct influence of the above-mentioned sites considered as emission sources of these metals.

During this second study period, winds blew from all directions, with varying frequencies and speeds, similar to those observed in the first period. Their speed fluctuated between 1.6 and $17.2 \mathrm{~m} / \mathrm{s}$ with an average of $6 \mathrm{~m} / \mathrm{s}$. Relying on the antagonistic "terrigenous/maritime" wind circulations, they can be seen to be characterized by frequencies equal to 52 and $48 \%$, respectively (compared to the total observations). At the first site (S14), the predominantly terrigenous circulation is responsible for a high $\mathrm{Ca}^{++}(39 \%)$ and $\mathrm{Fe}^{(2 ; 3)+}(34 \%)$ contribution rate compared to other constituents of the selected deposits (Figure 5a). The chlorine supply comes second with a rate of $6 \%$. The rates of the other items do not exceed $4 \%$. At the urban (coastal) S23 site ( $\approx 1.5 \mathrm{~km}$ off the coastline), the predominantly terrigenous circulation is responsible for a supply of $\mathrm{Ca}^{++}(21 \%), \mathrm{Fe}^{(2 ; 3)+}(20 \%), \mathrm{Cl}^{-}(20 \%), \mathrm{K}^{+}(17 \%)$ and $\mathrm{Na}^{+}(11 \%)$. The other items' rates are below 4\% (Figure 6a). 
Repartition rate of analyzed elements by terrigenious circulation (\%) S14

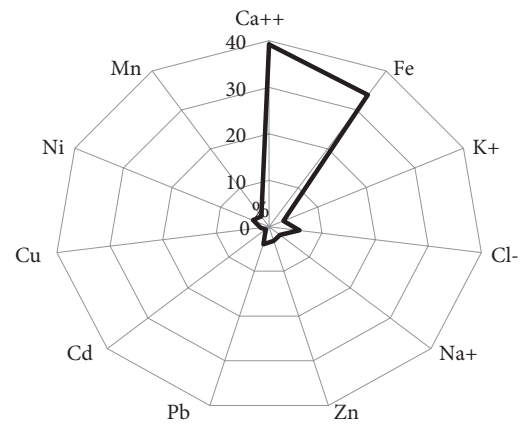

(a)

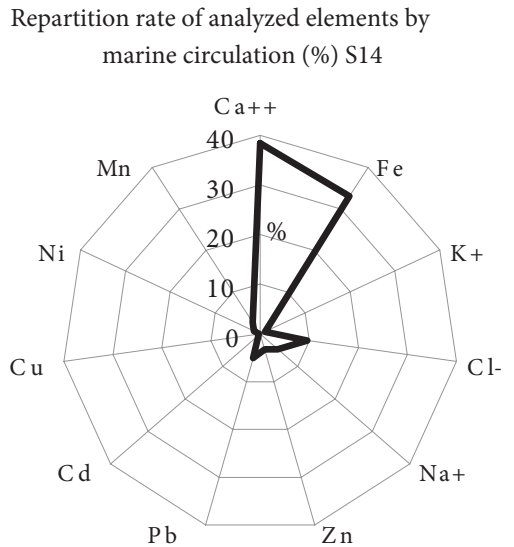

(b)

Figure 5. Repartition rate (\%) of biweekly fluxes constituents of particle deposition by terrigenious (a) and marine (b) circulations (Case of S14 site)

Repartition rate of analyzed elements by

terrigenious circulation (\%) S23

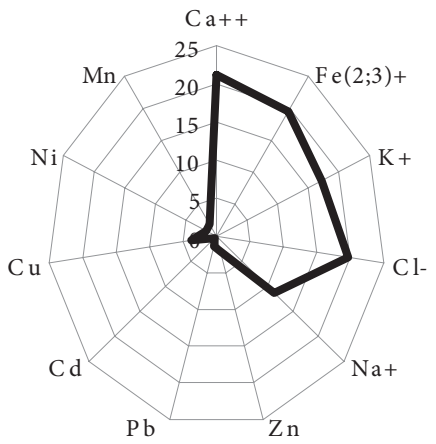

(a)
Repartition rate of analyzed elements by marine circulation (\%) S23

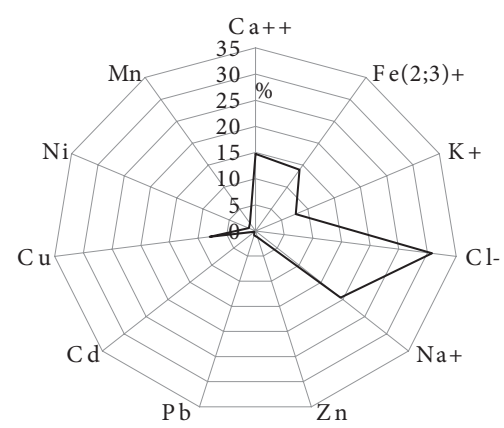

(b)

Figure 6. Repartition rate (\%) of biweekly fluxes constituents of particle deposition by terrigenious (a) and marine (b) circulations (Case of S23 site)

At S14, the predominantly maritime circulation is responsible for a strong $\mathrm{Ca}^{++}(38 \%), \mathrm{Fe}^{(2 ; 3)+}(33 \%)$, $\mathrm{Cl}^{-}(10 \%), \mathrm{Na}^{+}(5 \%$.) The percentages of the other items remain below 3\% (Figure 5b). On the other hand, it is responsible, at S23, for a high contribution of $\mathrm{Cl}^{-}(31 \%)$ (Figure 6b). The conributions of $\mathrm{Na}^{+}, \mathrm{Ca}^{++}, \mathrm{Fe}^{(2 ; 3)+}, \mathrm{Cu}$ and $\mathrm{K}^{+}$come in second place, with distribution rates varying from 8 to $19 \%$. The percentages of other items do not exceed $2 \%$.

The terrigene $\mathrm{Cl}^{-}$contribution rate, 6 and 20\% respectively at S14 and S23, is relatively high. Its maximum value is comparable to those supposed to be of terrigenous origin (case of $\mathrm{Fe}^{(2 ; 3)+}=20 \%$ for the case of S23).

Because of the maritime circulation prevalence, the importance of the contribution of elements believed to be originate of crustal source such as $\mathrm{Ca}^{++}$and $\mathrm{Fe}^{(2 ; 3)+}$ at S14 is possibly related to sea winds that have drained with them a crustal component emanating from eroded soils during transport. At site S23, their importance is possibly related to the phenomenon of road dust resuspension. This result has already been proved by Bahloul et al. (2015b).

The temporal evolution of the particulate deposits constituents at the two sites S14 and S23 also shows a great fluctuation (Tables 3 and 4). The lowest biweekly fluxes of the elements are attributed to rainy periods (in the case of campaigns $\mathrm{C} 2, \mathrm{C} 6, \mathrm{C} 9, \mathrm{C} 10$ and $\mathrm{C} 12$ ).

In order to investigate the influence of some meteorological parameters such as wind velocity, relative humidity and atmospheric pressure on the behaviour of particulate deposits in the selected sites, simple linear regression analysis was adopted. The main obvious results were as follows (Figures 7, 8 and 9):

- No significant correlations between wind speed and particulate deposit fluxes could be explained by the prevalence of the resuspension phenomenon effect (Figure 7). The marked frequency of relatively high wind speeds exceeding $7 \mathrm{~m} / \mathrm{s}$ ( $25 \%$ of the total observations) in the Monastir region could reinforce this phenomenon. Bahloul et al. (2015b) showed that velocities greater than $7 \mathrm{~m} / \mathrm{s}$ significantly accentuate 


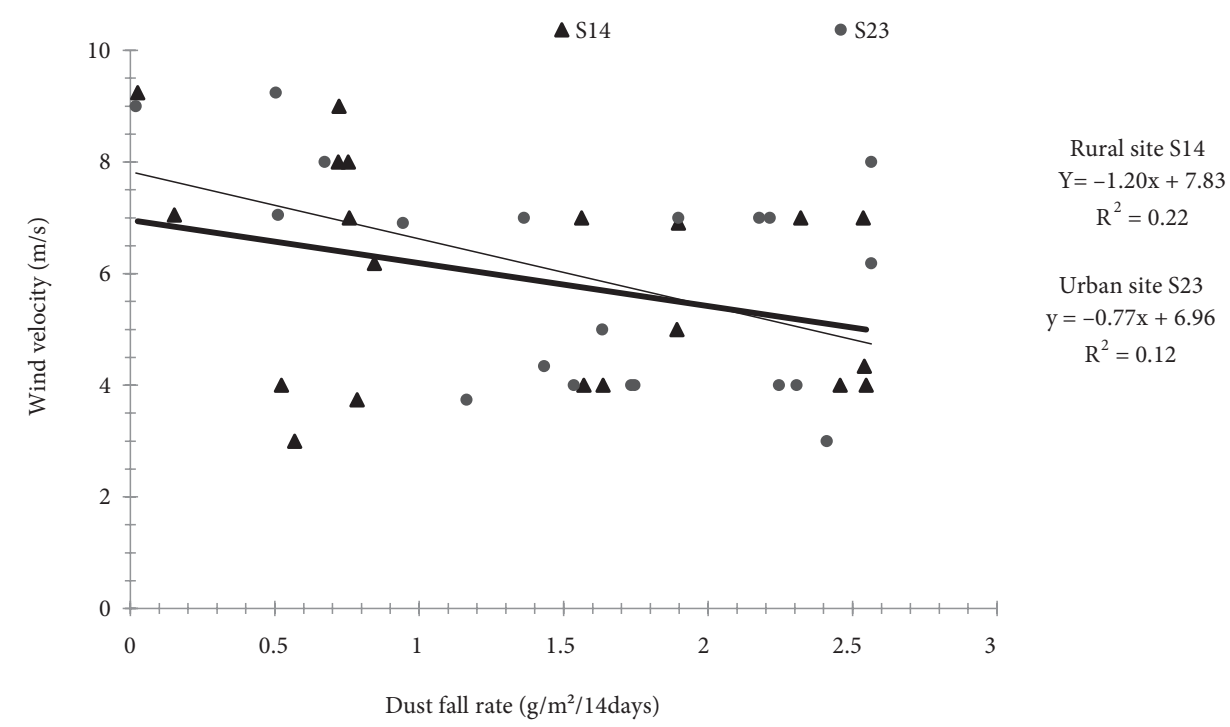

Figure 7. Regressions between wind velocity and biweekly flow deposits trough the two studied sites (S14 and S23)

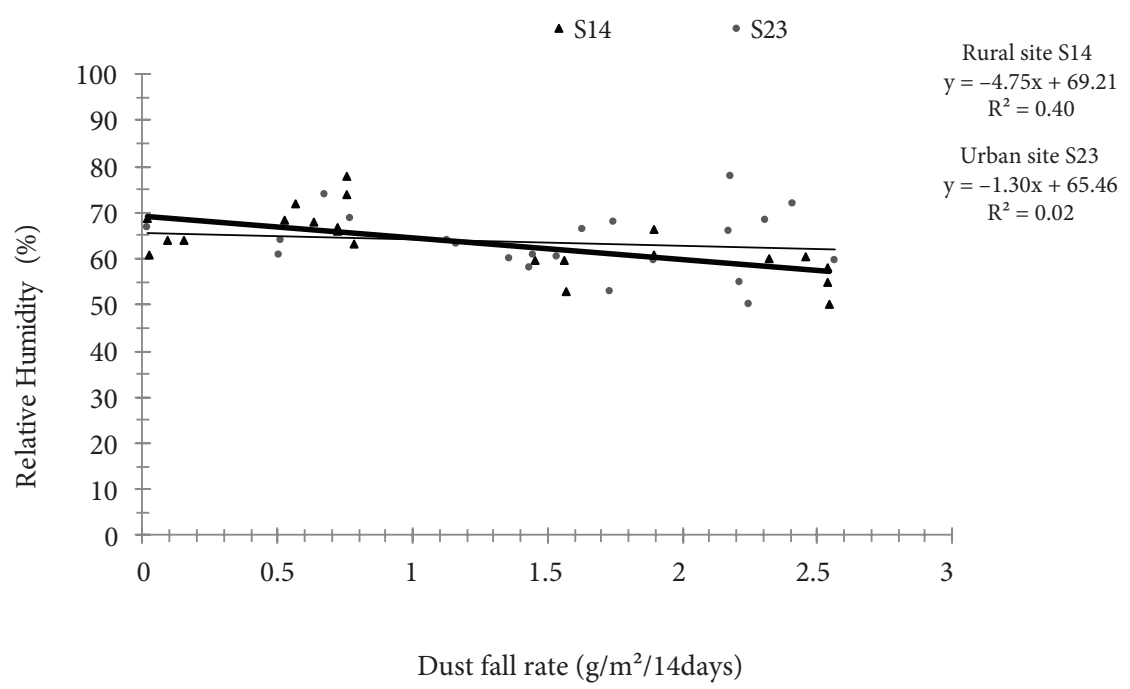

Figure 8. Regressions between relative humidity and biweekly flow deposits trough the two studied sites (S14 and S23)

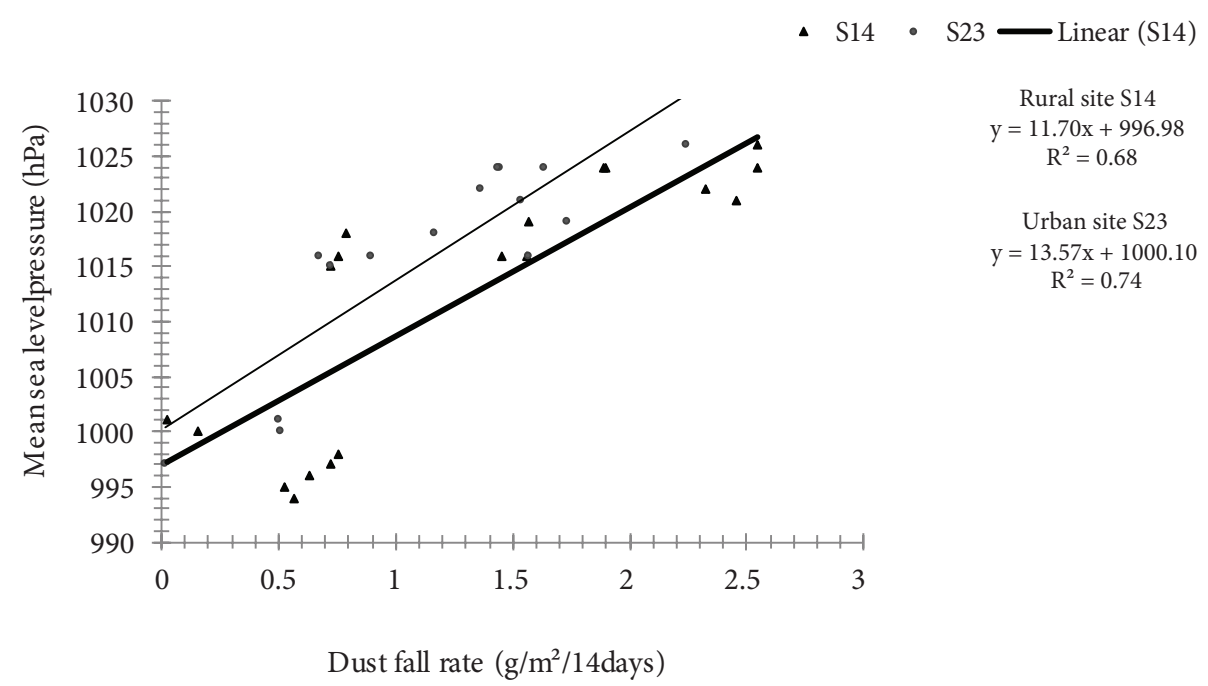

Figure 9. Regressions between mean sea level pressure and biweekly flow deposits trough the two studied sites (S14 and S23) 
the phenomenon of dust resuspension. The relatively high velocities normally promote the dilution of air components (including suspended particulate matter). In our case, the accentuation of deposits by such velocities is possibly linked to the obstacles effect (olive trees in the rural area and buildings in the urban sites) which, through the effect of winds enhance the poor diffusion of suspended solids, reinforcing their transfer to the ground. This result was already proved elsewhere (Azri, Abida, \& Medhioub, 2009b);

- No significant positive correlations between relative humidity and particulate deposits fluxes were observed (Figure 8). This could also testify for the non significant role of humidity in the gathering process reinforcing thereafter their transfer to the ground;

- The significant correlations between atmospheric pressure and particulate deposit fluxes (Figure 9) could be attributed first, to the turbulence action in the dilution of air constituents in the case of unstable meteorological conditions and second, to their accumulation in the case of stable meteorological conditions. For more refined analysis, a representation quality of the above meteorological parameters was also performed (Tables 5 and 6). The software used is the STATIT-CF (1986). The representation quality of parameters is identified by a coefficient, which explains its position in the factorial plane having the maximum of variance (in our case the $\mathrm{F} 1 \mathrm{xF} 2$ plane has the maximum of variance). It is given by the sum of the squares of the correlation coefficients between each parameter and the factorial axis of the considered plan (Dutot, Elichegaray,
\& Vie Le Sage, 1983; Azri et al. 2009a), as shown in the following Eq. (1):

$$
\operatorname{QLT}(j)=\sum_{j=1}^{n} r_{i}^{2}(j),
$$

where:

QLT ( $j$ ) - the representation QuaLiTy of the parameter j (\%o);

$r_{j}$ - the correlation coefficient between the parameter $\mathrm{j}$ and the factorial axis $\mathrm{i}$;

$n$ - the number of considered factorial axes.

This exercise showed that the atmospheric pressure is the parameter that had the best quality of representation both in the case of stable and unstable conditions. In these latter, the wind velocity has also a significant quality of representation. In this study, its role is reflected not only in the dilution phenomenon of airborne particulate matter but also in their fall to the surface (dust fall), reinforced by the presence of obstacles (olivetrees in rural zone and human dwellings in urban cities).

In order to more refine the above results and allow a better understand of the input sources effect, the use of chemometric approaches based on the enrichment factor calculation, the source contribution rate and the factorial analysis of correspondences remain of great interest.

\subsubsection{Chemometric approaches}

\subsubsection{Enrichment factor analysis}

Dealing with particulate deposits, several studies have shown that iron $(\mathrm{Fe})$ can be considered as a representative indicator of the terrigenous source. This element is

Table 5. Representation qualities (QLT) of selected meteorological parameters as a function of the two first axes of the (1x2) factoriel plane (\%) (Case of S14 site- the threshold of significance $=250$ for $\mathrm{p}<0.05$ and $\mathrm{n}=22$ )

\begin{tabular}{|l|l|c|c|c|}
\hline \multicolumn{1}{|c|}{ S14 } & \multicolumn{1}{|c|}{$\begin{array}{c}\text { Meteorological } \\
\text { parameters }\end{array}$} & $\begin{array}{c}\text { Factor 1 } \\
\mathrm{r}_{1}\end{array}$ & $\begin{array}{c}\text { Factor 2 } \\
\mathrm{r}_{2}\end{array}$ & $\begin{array}{c}\text { F1 x F2 Factorial plane } \\
\text { QLT (\%o) }\end{array}$ \\
\hline Stable conditions & Atmospheric pressure & 0.478 & 0.149 & $\mathbf{6 2 6 . 6 4 6}$ \\
& Wind speed & 0.179 & 0.014 & 212.901 \\
& Relative Humidity & 0.128 & 0.003 & 169.523 \\
\hline Unstable conditions & Atmospheric pressure & 0.391 & 0.296 & $\mathbf{6 8 6 . 7 6 2}$ \\
& Wind speed & 0.088 & 0.228 & $\mathbf{3 1 6 . 7 4 6}$ \\
& Relative humidity & 0.128 & 0.005 & 133.127 \\
\hline
\end{tabular}

Table 6. Representation qualities (QLT) of selected meteorological parameters as a function of the two first axes of the (1x2) factoriel plane $(\%)$ (Case of S23 site- the threshold of significance $=250$ for $p<0.05$ and $n=22$ )

\begin{tabular}{|l|l|c|c|c|}
\hline \multicolumn{1}{|c|}{ S23 } & \multicolumn{1}{|c|}{$\begin{array}{c}\text { Meteorological } \\
\text { parameters }\end{array}$} & $\begin{array}{c}\text { Facto 1 } \\
\mathrm{r}_{1}\end{array}$ & $\begin{array}{c}\text { Factor 2 } \\
\mathrm{r}_{2}\end{array}$ & $\begin{array}{c}\text { F1 x F2 Factorial plane } \\
\text { QLT (\%o) }\end{array}$ \\
\hline Stable conditions & Atmospheric pressure & 0.049 & 0.720 & $\mathbf{7 6 9 . 3 0 2}$ \\
& Wind speed & 0.211 & 0.002 & 212.901 \\
& Relative Humidity & 0.165 & 0.005 & 169.523 \\
\hline Unstable conditions & Atmospheric pressure & 0.505 & 0.0001 & $\mathbf{5 0 5 . 5 6 7}$ \\
& Wind speed & 0.257 & 0.047 & $\mathbf{3 0 4 . 7 9 8}$ \\
& Relative humidity & 0.154 & 0.026 & 180.813 \\
\hline
\end{tabular}


widely used as a crustal reference (Feng, Cochran, Lwiza, Brownawell, \& Hirschberg, 1998; Schiff \& Weisberg, 1999; Mucha, Vasconcelos, \& Bordalo, 2003; Zhou, Guo, \& Hao, 2007; Zhang et al., 2007). It is very abundant in the earth's crust (50000 ppm) and slightly emitted by the marine source (0.002 ppm). In Monastir crust (regional background), it is also abundant (Table 7). Furthermore, its anthropogenic emissions are negligible (Chabbi, 2012). Consequently, this element is considered in our study as a crustal reference to study the enrichment of the particulate deposits with respect to the crust.

Because of their abundance in the marine source, sodium and chlorine can be considered as marine benchmarks. However, the availability of sodium of terrigenous

Table 7. Background levels of some heavy metals in Monastir region $(\mathrm{mg} / \mathrm{kg})($ Serbaji, 2000)

\begin{tabular}{|c|c|}
\hline Elements & Monastir background levels $(\mathrm{mg} / \mathrm{kg})$ \\
\hline $\mathrm{Fe}$ & 10000 \\
$\mathrm{Zn}$ & 61 \\
$\mathrm{Ni}$ & 7 \\
$\mathrm{Cu}$ & 10 \\
$\mathrm{Cd}$ & 4 \\
\hline
\end{tabular}

origin in a non-negligible quantity $(\mathrm{Na} / \mathrm{Fe}=0.56$, Mason, 1966) has led us to opt for chlorine as a marine reference element. This element is scarce in the earth's crust (130 ppm, Mason, 1966) and very abundant in seawater (18800 ppm, Brewer, 1975). Its selection in this study is also based on the analysis of its particular temporal evolution, which is different from that of other elements supposed to be mostly of crustal origin.

Thus, referring to the selected $\mathrm{Cl}$ and $\mathrm{Fe}$, chosen respectively as marine and terrigenous source references, the enrichment factors (EF) of the various elements are determined by formulae (2 and 3 ):

$$
\begin{aligned}
& \mathrm{EF} / \text { crust }=\frac{(\mathrm{X} / \mathrm{Fe})_{\text {deposits }}}{(\mathrm{X} / \mathrm{Fe})_{\text {background }}} . \\
& \mathrm{EF} / \text { sea water }=\frac{(\mathrm{X} / \mathrm{Cl})_{\text {deposits }}}{(\mathrm{X} / \mathrm{Cl})_{\text {sea water }}} .
\end{aligned}
$$

and can be classified into three categories:

- little or no enriched: $\mathrm{EF}<10$;

- enriched: $10<\mathrm{EF}<1000$;

- highly enriched: EF $>1000$.

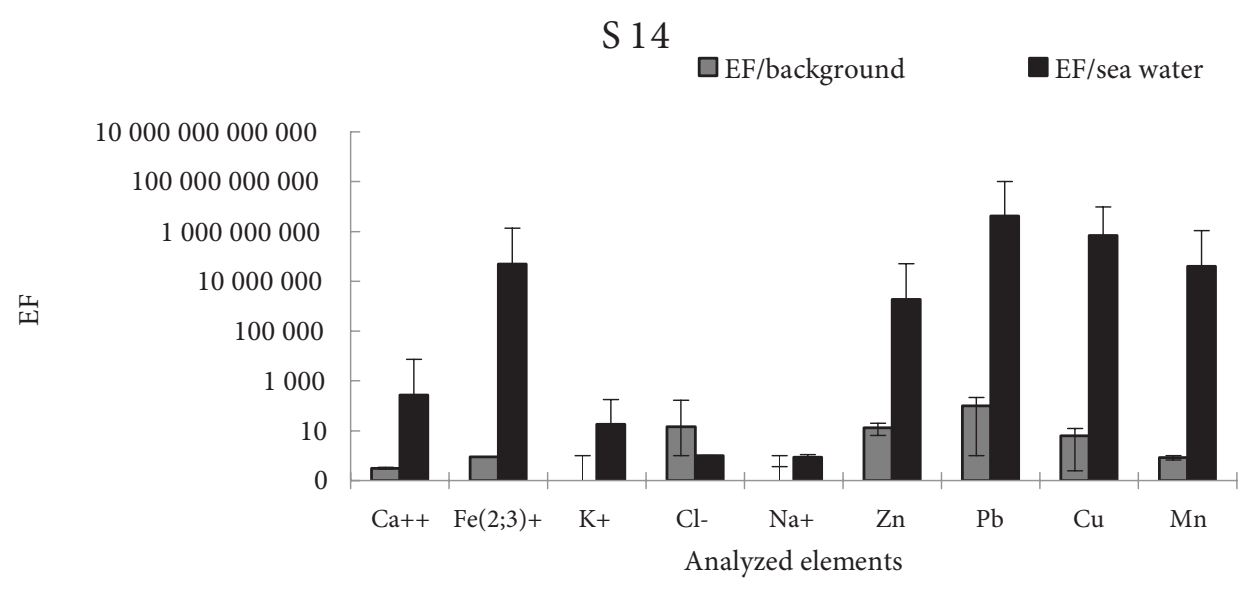

Figure 10. Enrichment factors of particle deposition constituents referred to $\mathrm{Fe}$ and $\mathrm{Cl}$ (for S14 site)

\section{S $23 \square \mathrm{EF} /$ background $\mathbf{E F} /$ sea water}

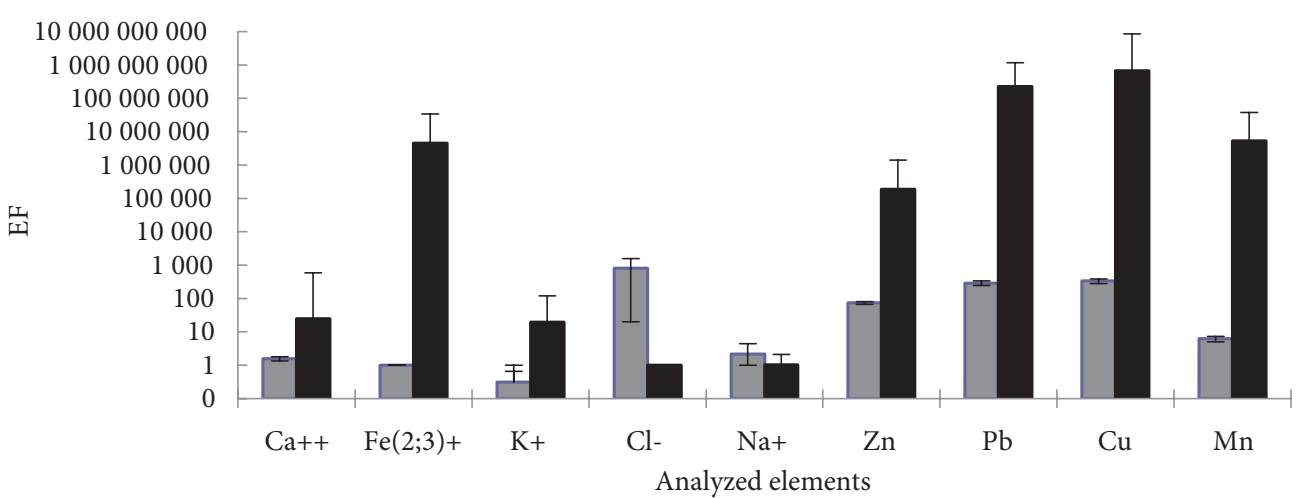

Figure 11. Enrichment factors of particle deposition constituents referred to Fe and $\mathrm{Cl}$ (for S23 site) 
Generally, an element is assumed to be of a natural origin if its enrichment factor (EF) is less than 10 (Chester, Nimmo, \& Preston, 1999; Saliba, Kouyoumdjian, \& Roumie, 2007). Based on Monastir crust, as a regional background (Serbaji, 2000) and averages of chemical constituents in sea water (Brewer, 1975), the enrichment factors of the different analyzed elements have been computed. These factors corresponding data are illustrated in Figures 10 and 11. From this data, one can deduce:

$-\mathrm{Fe}^{(2 ; 3)+}, \mathrm{Ca}^{++}$, and $\mathrm{K}^{+}$are essentially of crustal origin. They are slightly enriched relative to the crust $(\mathrm{EF}<10)$ and enriched to highly enriched with respect to sea water $\left(10<\mathrm{EF}<10^{8}\right)$;

$-\mathrm{Cl}^{-}$is typically marine. It is non-enriched with respect to sea water $(\mathrm{EF}<10)$ and enriched with respect to the crust $(\mathrm{EF}>10)$;

- Na is slightly enriched in relation to both crust and sea water. It has a mixed origin related to these two sources.

$\mathrm{Pb}, \mathrm{Mn}, \mathrm{Zn}$, and $\mathrm{Cu}$ are enriched relative to the crust $(\mathrm{EF}>10)$ and highly enriched refering to seawater $\left(10<\mathrm{EF}<10^{10}\right)$. They come from other sources than terrigenious and marine. In the absence of nearby industrial sources, the anthropogenic component attributed to the aforementioned metals is possibly due to the traffic activity. The two main medium-population density of touristic towns (Monastir and Mahdia) together with the various small urban agglomerations spread along the coast in the eastern part of the region, can fully justify the importance of the traffic activity in this area. With the agricultural character of its western part, the railway and motorway with their intense fluidity $(\approx 10 \mathrm{~km})$ linking the Southern Tunisia regions with those of the North, can enrich the atmosphere of this zone by such metals. Although the unleaded petrol has significantly reduced lead emissions in the air today, this substance still remains in exhaust emissions and brake pads. Therefore, it is still a road transport marker (Kummer, Pacyna, \& Friederich, 2009). As a Pb substitute, Methylcyclopentadienyl Manganese Tricarbonyl (MMT) is now an additive of unleaded petrol as an anti-detoning agent. The Mn concentration has increased in the atmosphere since its introduction as one of the components of this petrol (Joly et al., 2011). It is toxic and may lead to psychiatric and neurological disorders or even mental retardation (Zayed, Hong, \& Espérance, 1999). $\mathrm{Zn}$ and $\mathrm{Cu}$ emissions are due to lubricant leakage, exhaust emission and erosion of the security guardrails (Hueglin et al., 2005).

The enrichment factor results and those of the aforementioned descriptive study showed that under the predominantly terrigenous wind circulations, the $\mathrm{Cl}^{-}$contribution rates (6 and 20\% at S14 and S23, respectively) are relatively important. Its maximum value is comparable to those of terrigenous origin elements $\left(\mathrm{Fe}^{(2 ; 3)+}=20 \%\right.$, at S23). This was mainly attributed to the significant effect of the sebkhas located in the Tunisian Sahel (Sidi El Hani $\approx 370 \mathrm{~km}^{2}$, El Moknine $\approx 50 \mathrm{~km}^{2}$, Sahline $\approx 26 \mathrm{~km}^{2}$ ) (Figure 1). Their contribution in chlorine was developed in the following paragraph.

\subsubsection{The Sebkha's chlorine contribution rate}

Several analytical approaches have been adopted to estimate the chlorine contribution rate of the above-mentioned sebkhas. Such approaches have already been published in Bahloul et al. (2015b). They are based on the use of the following formulae (4 and 5):

Relying on the assumption that $100 \%$ of $\mathrm{Fe}$ originates from the crust; the biweekly estimated fluxes of crustal chlorine $(\mathrm{Cl})_{\text {deposits }}^{\text {crustal }}$ (expressed in $\mathrm{g} / \mathrm{m}^{2}$ ) in atmospheric particulate deposits are first given by equation (4):

$$
\begin{aligned}
& (\mathrm{Cl})_{\text {deposits }}^{\text {crustal }}= \\
& (\mathrm{Cl} / \mathrm{Fe})_{\text {crust"Mason model" }} x(\mathrm{Fe})_{\text {deposits }} .
\end{aligned}
$$

$(\mathrm{Fe})_{\text {deposits }}$ : Fe Biweekly fluxes measured in atmospheric particulate deposits $\left(\mathrm{g} / \mathrm{m}^{2}\right)$.

and second, the crust source contribution rate in chlorine is determined by formula (5):

$$
\begin{aligned}
& \text { Crustal rate }(\%)= \\
& {\left[(\mathrm{Cl})_{\text {deposits }}^{\text {crustal }} /(\mathrm{Cl})_{\text {deposits }}\right] \times 100 .}
\end{aligned}
$$

$(\mathrm{Cl})_{\text {deposits }}$ : Biweekly fluxes of total $\mathrm{Cl}$ measured in atmospheric particulate deposits $\left(\mathrm{g} / \mathrm{m}^{2}\right)$.

The estimated crustal source contribution rates in terms of chlorine, related to S14 and S23 sites, are presented in Tables 8 and 9 respectively. The results show that the crustal source contribution rate in terms of $\mathrm{Cl}$ is variable under the terrigenious wind directions. Indeed, it is demonstrated that the contribution rate is relatively high with winds blowing "from SSW to W directions", for S14 and "from S to WSW directions" for S23 (80 and 82\% of total crustal chlorine for S14 and S23, respectively).

The above wind sectors are defined as the meteorological factor in which the study sites (S14 and S23) were placed downstream the Sidi El Hani and Moknine sebkhas (Figure 1).

The rather high crustal chlorine contribution rate recorded at S23 compared to that recorded at S14 could be explained by the relatively high exposure frequency of S23 to the terrigenious winds blowing over Sidi El Hani and Moknine sebkhas ( $31 \%$ of total observations) compared to those relative to $\mathrm{S} 14$ (16\% of total observations).

On the other hand, the estimated chlorine contribution rate of marine source was based on formulae (6) and (7) (Belghith, 1999; Azri et al., 2009b): 
Table 8. Estimated crustal source contribution rate in terms of chlorine (S14)

\begin{tabular}{|l|c|c|}
\hline \multicolumn{1}{|c|}{ Predominantly wind circulation } & $\begin{array}{c}\text { Distribution frequency (\% } \\
\text { with respect to total } \\
\text { observations) }\end{array}$ & $\begin{array}{c}\text { Contribution crustal source rate in } \\
\text { terms of Cl (\%) }\end{array}$ \\
\hline Terrigenious & 52 & 1.20 (of total chlorine) \\
\hline $\begin{array}{l}\text { South south west to west dominant wind sector } \\
\text { (meteorological condition in which the study site } \\
\text { was placed downstream Sidi El Hani sebkha) }\end{array}$ & 36 & 0.96 (80 total crustal chlorine) \\
\hline $\begin{array}{l}\text { Other terrigenious wind directions (case in which } \\
\text { the study site cannot be placed downstream } \\
\text { sebkhas) }\end{array}$ & & \\
\hline
\end{tabular}

Table 9. Estimated crustal source contribution rate in terms of chlorine (S23)

\begin{tabular}{|l|c|c|}
\hline \multicolumn{1}{|c|}{ Predominantly wind circulation } & $\begin{array}{c}\text { Distribution frequency (\% } \\
\text { with respect to total } \\
\text { observations) }\end{array}$ & $\begin{array}{c}\text { Contribution crustal source rate in } \\
\text { terms of Cl (\%) }\end{array}$ \\
\hline Terrigenious & 52 & 5.12 (of total chlorine) \\
\hline $\begin{array}{l}\text { South dominant wind direction (meteorological condition } \\
\text { in which the study site was placed downstream Moknine } \\
\text { sebkha) and dominant wind sector from south south west } \\
\text { to west south west (impact of Sidi El Hani sebkha on } \\
\text { study site) }\end{array}$ & 31 & 0.20 of total crustal chlorine) \\
\hline $\begin{array}{l}\text { Other terrigenious wind directions (case in which the } \\
\text { study site cannot be placed downstream sebkhas) }\end{array}$ & 21 & $0.92 \%$ of total crustal chlorine) \\
\hline
\end{tabular}

First, the biweekly estimated marine chlorine fluxes of atmospheric particulate deposits $(C l)_{\text {deposits }}^{\text {marine }}$ (expressed in $\mathrm{g} / \mathrm{m}^{2}$ ) are given by Eq. (6):

$$
(C l)_{\text {deposits }}^{\text {marine }}=(C l)_{\text {measured }}-(C l)_{\text {deposits }}^{\text {crustal }} .
$$

$(\mathrm{Cl})_{\text {measured }}$ : Biweekly fluxes of total $\mathrm{Cl}$ measured in atmospheric particulate deposits $\left(\mathrm{g} / \mathrm{m}^{2}\right)$

Second, the estimated contribution rate of marine source is determined by $\mathrm{Eq}(7)$ :

$$
\text { Marine rate }(\%)=\left[(C l)_{\text {deposits }}^{\text {marine }} /(C l)_{\text {deposits }}\right] \times 100 \text {. }
$$

The results show rates nearly equal to 98.8 and $94.9 \%$ of total chlorine for the S14 and S23 respectively. Based on these results, we can deduce that, in spite of the weak chlorine crustal contribution rate compared to that of marine source (1.2 and $5.12 \%$ against 98.8 and $94.9 \%$ of total chlorine for S14 and S23, respectively), its highest value (80 and $82 \%$ of the total crustal chlorine for S14 and S23, respectively) was computed under the terrigenious winds blowing over the previously cited sebkhas.

In order to refine the obtained results by the enrichment factors and to better identify the contribution sources, a factorial analysis of correspondences has been performed.

\subsubsection{Factorial analysis of correspondences}

The factorial analysis of correspondences applied to all data: Biweekly fluxes of analyzed elements $\left(\mathrm{g} / \mathrm{m}^{2}\right)$ of dry particulate deposits and principal meteorological parameters) using the ITCF statistical software package (STATITCF, 1986), resulted essentially in three main components. A varimax rotation with Kaiser Normalization was used for all data. The considered significance threshold ( $r$ ) for $\mathrm{p}<0.05$ is equal to 0.42 , after a test of Student's $(\mathrm{n}=22)$. The significant correlations between the selected parameters (variables) and the components represent approximately 64.43 and $63.95 \%$ of the total variance for S14 and S23, respectively. For S14, the first, second and third FACs explained, $34.79,19.19$ and $10.45 \%$ of the total variance. For S23, they explained $34.88,18.26$ and $10.81 \%$ of the total variance.

The projections over the $1 \times 2$ factorial planes (presenting the maximum of inertia; $=53.98$ and $53.14 \%$ for S14 and S23, respectively) of all selected variables show a similar distribution for the two sites with distinct data groups (Figures 12 and 13):

- A first group (G1) consists of $\mathrm{Fe}^{(2 ; 3)+}, \mathrm{Ca}^{++}, \mathrm{K}^{+}, \mathrm{Mn}$, $\mathrm{Ni}, \mathrm{Cd}, \mathrm{Zn}, \mathrm{Pb}, \mathrm{Cu}, \mathrm{V} 1, \mathrm{~V} 2, \mathrm{P} 3, \mathrm{~S} 3, \mathrm{RH} 1$. It is characterized by the effect of terrigenous winds distinguished by a very steady atmosphere (P3) associated with low and moderate velocities (V1 and V2) favourable to the accentuation of both crustal $\left(\mathrm{Fe}^{(2 ; 3)+}\right.$, 


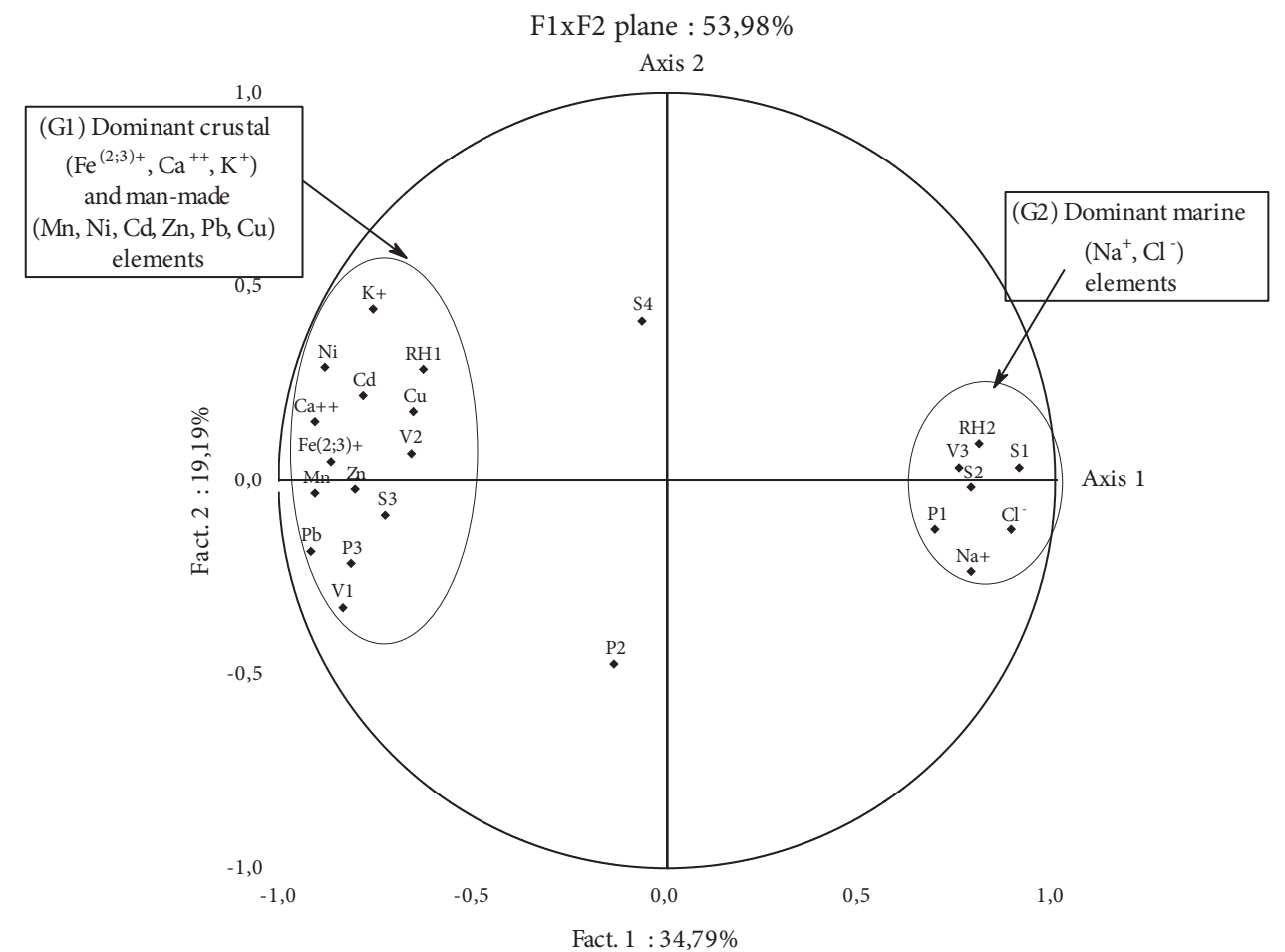

Figure 12. Distribution of biweekly fluxes constituents of particle deposition in the correlation circle (for S14 site; $\mathrm{r}=0.42$ for $\mathrm{p}<0.05$ and $\mathrm{n}=22$ )

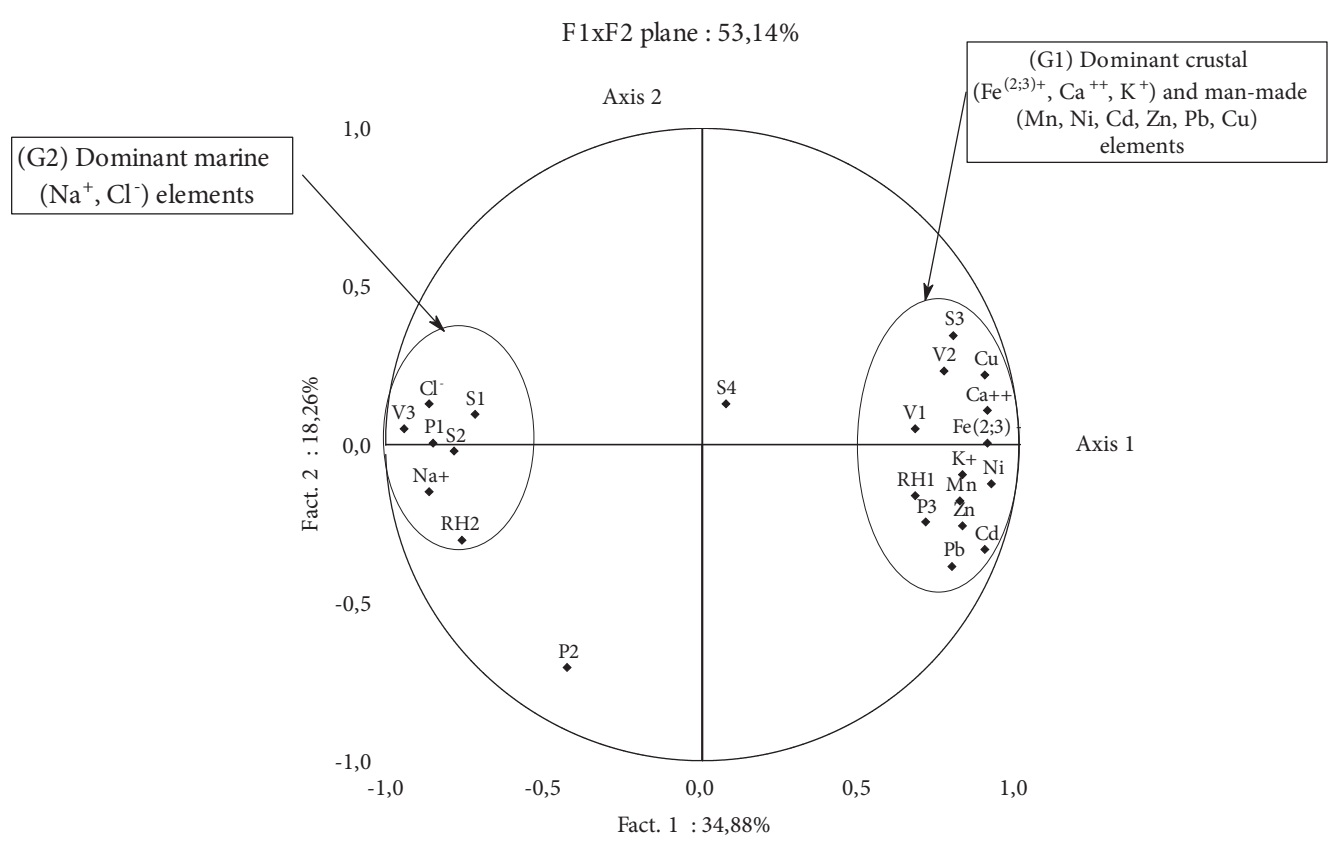

Figure 13. Distribution of biweekly fluxes constituents of particle deposition in the correlation circle (for S23 site; $\mathrm{r}=0.42$ for $\mathrm{p}<0.05$ and $\mathrm{n}=22$ )

$\left.\mathrm{Ca}^{++}, \mathrm{K}^{+}\right)$and man-made $(\mathrm{Mn}, \mathrm{Ni}, \mathrm{Cd}, \mathrm{Zn}, \mathrm{Pb}, \mathrm{Cu})$ elements. The association of these elements is clear enough under the prevalence of the western sector wind (S3) which carries especially the highway traffic emissions to the study sites. These terrigenous winds are demonstrated to be relatively dry $(\mathrm{RH}<50 \%)$;
- A second group (G2) includes $\mathrm{Na}^{+}, \mathrm{Cl}^{-}, \mathrm{RH} 2, \mathrm{~V} 3$, $\mathrm{P} 1$ and S1, S2. It is representative of marine circulation effect characterized by the dominance of eastern winds with relatively high velocities. These are distinct under unstable meteorological conditions. 


\section{Conclusions}

The particulate deposit fluxes study in the Monastir region shows an obvious spatio-temporal variability. These deposit spatial evolution shows very distinct patterns with variable amplitudes. Zonal differentiation is eventually attributed to the effect of nearby sources (brick kilns and clay quarries, road traffic and sebkhas), obstacles and meteorological factors (including precipitation and wind speed).

The temporal evolution of the particulate deposit components $\left(\mathrm{Fe}^{(2 ; 3)+}, \mathrm{Ca}^{++}, \mathrm{Na}^{+}, \mathrm{K}^{+}, \mathrm{Cl}^{-}, \mathrm{Pb}, \mathrm{Cu}, \mathrm{Cd}, \mathrm{Zn}, \mathrm{Ni}\right.$ et $\mathrm{Mn})$ at two particular sites receiving the highest particulate fluxes (S14 and S23) also shows a large fluctuation.

The enrichment factor results of the source contribution rate as well as the descriptive study show that, under predominantly terrigenous winds, the $\mathrm{Cl}^{-}$contribution rate (6 and 20\% at S14 and S23 sites, respectively) is relatively noticeable. Its maximum value is comparable to those of the supposed elements of terrigenous origin $\left(\mathrm{Fe}^{(2 ; 3)+}=20 \%\right.$, at site S23). This is attributed to the significant effect of sebkhas located in the Tunisian Sahel, namely (Sebkha Sidi El Hani $\approx 370 \mathrm{~km}^{2}$, Sebkha El Moknine $\approx 50 \mathrm{~km}^{2}$, and Sebkha Sahline $\approx 26 \mathrm{~km}^{2}$ ).

The factorial analysis of correspondences applied to the atmospheric data (soluble and insoluble fractions of particulate deposits and meteorological parameters) reveal similar groups for the two sites S14 and S23. It also shows, on one hand, the effect of terrigenious winds blowing from the western sector under the steady atmospheric situations associated with low and moderate velocities favourable to the accentuation of both crustal $\left(\mathrm{Fe}^{(2 ; 3)+}, \mathrm{Ca}^{++}, \mathrm{K}^{+}\right)$and man-made ( $\mathrm{Mn}, \mathrm{Ni}, \mathrm{Cd}, \mathrm{Zn}, \mathrm{Pb}, \mathrm{Cu}$ ) elements. On the other hand, it confirms the effect of marine circulation characterized by the dominance of eastern winds with relatively high velocities. These are obvious under unstable meteorological conditions.

Consequently, we can conclude that particle deposition even at rural areas is most influenced by closed manmade sources, obstacles and meteorological patterns, with the largest influence by the traffic sources and the reshuffle phenomenon. The relatively high contribution rate of crustal chlorine under terrigenious wind's direction can be then attributed to nearby sebkhas. Therefore, they may be considered as nonnegligible feeding sources of airborne particulate matter enriched with chlorine.

More in-depth studies can provide evidence about the challenges related to environmental sustainability and the implementation of active measures to reduce the adverse effects of particulate deposition. It is therefore to take the following considerations into account:

- strengthening the control network of both dry and wet particulate deposition;

- brickyards and clay quarries are required to install dedusting tools;

- pragrammes aimed at modernize the fleets as well as at rehabilitate the railways by the acquisition of unused trains (in Tunisia, some trains have already been used for more than fifty years);

- encouraging the use of public transit;

- more encourage the use of environmentally friendly fuel such as LPG (Liquefied Petroleum Gas) which considred as an alternative fuel. In Tunisia, while the abundance of distribution stations of this type of fuel, its use remains limited with the exception of some kinds of car (taxis and older vehicles).

\section{Conflict of Interests}

The authors declare that there is no conflict of interests regarding the publication of this paper.

\section{Acknowledgements}

The authors would like to thank Mrs Abdelmajid Dammak and Fathi Bourmech, English language Professors, respectively, at the National School of Engineers at Sfax and the Faculty of Arts at Sfax for careful editing and proofreading of this paper.

\section{References}

Allen, A. G., Nemitz, E., Shi, J. R., Harrison, R. M., \& Greenwood, J. C. (2001). Size distribution of trace metals in atmospheric aerosols in the United Kingdom. Atmospheric Environment, 35(27), 4581-4591.

https://doi.org/10.1016/S1352-2310(01)00190-X

Azri, C., Abida, H., \& Medhioub, K. (2009b). Geochemical behavior of the Tunisian background aerosols in sirocco wind circulations. Advances in Atmospheric Sciences, 26(3), 390402. https://doi.org/10.1007/s00376-009-0390-8

Azri, C., Chaabane, M., Abida, H., \& Medhioub, K. (2010). Water-soluble components in PM10 aerosols over an urban and a suburban site in the city of Sfax (Tunisia). Atmosfera, 23(2), 197-211.

Azri, C., Chaabane, M., \& Medhioub, K. (2009a). Diurnal evolutions of Nitrogen oxides (NOx), Ozone (O3) and PM10 particles at a busy traffic cross-road in the city of Tunis. Environmental Progress \& Sustainable Energy, 28(1), 143-154. https://doi.org/10.1002/ep.10315

Azri, C., Maalej, A., \& Medhioub, K. (2000). Etude de la variabilité des constituants de l'aérosol dans la ville de Sfax (Tunisie), Pollution Atmosphérique, (165), 121-129.

https://doi.org/10.4267/pollution-atmospherique.3021

Bae, S. Y., Yi, S. M., \& Kim, Y. P. (2002). Temporal and spatial variations of the particle size distribution of PAHs and their dry deposition fluxes in Korea. Atmospheric Environment, 36(35), 5491-5500. https://doi.org/10.1016/S1352-2310(02)00666-0

Bahloul, M., Chabbi, I., Dammak, R., Amdouni, R., Medhioub, K., \& Azri, C. (2015b). Geochemical behaviour of PM10 aerosol constituents under the influence of succeeding anticyclonic/ cyclonic situations: case of Sfax City, southern Tunisia. Environmental Monitoring and Assessment, (187), 1-17. https://doi. org/10.1007/s10661-015-4980-x

Bahloul, M., Chabbi, I., Sdiri, A., Amdouni, R., Medhioub, K., \& Azri, C. (2015a). Spatiotemporal variation of particulate fallout instances in Sfax City, Southern Tunisia: influence of sources and meteorology. Advances in Meteorology, Article ID $471396,11 \mathrm{p}$. 
Belghith, I. (1999). Study of the atmospheric aerosol in the region of Sfax: influence of local and synoptic meteorological conditions: $\mathrm{PhD}$ dissertation. University of Tunis II.

Bond, T. C., Streets, D. G., Yarber, K. F., Nelson, S. M., Woo, J. H., \& Klimont, Z. (2004). A technology-based global inventory of black and organic carbon emissions from combustion. Journal of Geophysical Research, 109(D14), 1029-14203. https://doi.org/10.1029/2003JD003697

Borghezi, D., Vione, D., Maurino, V., \& Minero, C. (2005). Transformation of benzene photo induced by nitrate salts and iron oxide. Journal of Atmospheric Chemistry, 52(3), 259-281. https://doi.org/10.1007/s10874-005-5304-2

Brewer, P. G. 1975. Minor elements in sea water, chemical oceanography. In Riley JPO. G. Skirrow (Eds). (2 ${ }^{\text {nd }}$ ed.). London: Academic Press, 80, 415-495.

Cao, Z., Yang, Y., Lu, J., \& Zhang, C. (2011). Atmospheric particle characterization, distribution, and deposition in Xian, Shaanxi Province, Central China. Environmental Pollution, 159(2), 577-584. https://doi.org/10.1016/j.envpol.2010.10.006

Cerro, J. C., Caballero, S., Bujosa, C., Alastuey, A., Querol, X., \& Pey, J. (2014). Aerosol Deposition in Balearic Islands as Overview of the deposition in the Western Mediterranean. In Proceedings of the $2^{\text {nd }}$ Iberian Meeting on Aerosol Science and Technology, 2014, RICTA, Tarragona, Spain.

Chabbi, I. (2012). Etude de la variabilité spatio-temporelle des retombées atmosphériques au dessus d'une zone rurale-cas de la région de Zéramdine (Monastir). Mastère en sciences géologiques de la Faculté des Sciences de Sfax. Tunisie.

Chester, R., Nimmo, M., \& Preston, M. R. (1999). The trace metal chemistry of atmospheric dry deposition samples collected at Cap Ferrat: a coastal site in the Western Mediterranean. Marine Chemistry, 68(1-2), 15-30.

https://doi.org/10.1016/S0304-4203(99)00062-6

Chung, Y. S., Kim, K. S., Park, K. H., Jugder, D., \& Tao, G. (2005). Observations of dust storms in China, Mongolia and associated dust falls in Korea in spring 2003. Water, Air, \& Soil Pollution, 5(3-6), 15-35. https://doi.org/10.1007/s11267-005-0724-1

Cindoruk, S. S., \& Tasdemir, Y. (2007). Deposition of atmospheric particulate PCBs in suburban site of Turkey. Atmospheric Research, 85(3-4), 300-309.

https://doi.org/10.1016/j.atmosres.2007.02.002

Dammak, R., Bahloul, M., Chabbi, I., \& Azri, C. (2016). Spatial and temporal variations of dust particle deposition at three "urban/suburban" areas in Sfax city (Tunisia). Environmental Monitoring and Assessment, (188), 1-14. https://doi.org/10.1007/s10661-016-5341-0

Dutot, A. L., Elichegaray, C., \& Vie Le Sage, R. (1983). Application de l'analyse des correspondances à l'étude de la composition physico-chimique de l'aérosol urbain. Atmospheric Environment, 17(1), 73-78. https://doi.org/10.1016/0004-6981(83)90009-4

Ediagbonya, T. F., Ukpebor, E. E., Okiemien, F. E., \& Okungbowa, G. E. (2013). Spatio-temporal distribution of inhalable and respirable particulate matter in rural atmosphere of $\mathrm{Ni}$ geria. Environmental Skeptics and Critics, 2, 20-29.

Fang, G. C., \& Wu, Y. S. (1999). Modeling dry deposition of total particle mass in trafficked and rural sites of Central Taiwan. Environment International, 25(5), 625-633.

https://doi.org/10.1016/S0160-4120(99)00021-5

Fang, G. C., Wu, Y. S., Wen, C. C., Huang, S. H., \& Rau, J. Y. (2006). Ambient air particulate concentrations and metallic elements principal component analysis at Taichung Harbor (TH) and WuChi Traffic (WT) near Taiwan Strait during 2004-2005. Journal of Hazardous Materials, 137(1), 314-323. https://doi.org/10.1016/j.jhazmat.2006.02.017
Feng, H., Cochran, J. K., Lwiza, H., Brownawell, B., \& Hirschberg, D. J. (1998). Distribution of heavy metal and PCB contaminants in the sediments of an urban estuary: the Hudson River. Marine Environmental Research, 45(1), 69-88. https://doi.org/10.1016/S0141-1136(97)00025-1

Gabet, M. C. (1999). Dépôt de poussières au voisinage des tunnels routiers. Centre d'étude des tunnels, Lyon (France).

Geraldine, A., Maul, A., Ferard, J., Carrot, F., \& Ayrault, S. (2004). Spatial variability of sampling : impact on atmospheric metals and trace elements deposition mapping with mosses. Journal of Atmospheric Chemistry, 49(1-3), 39-52. https://doi.org/10.1007/s10874-004-1213-Z

Guerzoni, S., Molinaroli, E., Rossini, P., Rampazzo, G., Quarantotto, G., De Falco, G., \& Cristini, S. (1999). Role of desert aerosol in metal fluxes in the Mediterranean area. Chemosphere, 39(2), 229-246. https://doi.org/10.1016/S0045-6535(99)00105-8

Hueglin, C., Gehriga, R., Baltenspergerb, U., Gyselc, M., Monnd, C., \& Vonmonta, H. (2005). Chemical characterisation of PM2.5, PM10 and coarse particles at urban, near-city and rural sites in Switzerland. Atmospheric Environment, 39(4), 637-651. https://doi.org/10.1016/j.atmosenv.2004.10.027

Joly, A., Lambert, J., Gagnon, C., Kennedy, G., Mergler, D., Adam-Poupart, A., \& Zayed, J. (2011). Reduced atmospheric Manganese in Montreal following removal of Methylcyclopentadienyl Manganese Tricarbonyl (MMT). Water, Air, \& Soil Pollution, 219(1), 263-270.

https://doi.org/10.1007/s11270-010-0704-6

Królak, E. (2000). Heavy metals in falling dust in Eastern Mazowieckie Province. Polish Journal of Environmental Studies, 9, 517-522.

Kubilay, N., \& Saydam, A. C. (1995). Trace elements in atmospheric particulates over the Eastern Mediterranean; concentrations, sources, and temporal variability. Atmospheric Environment, 29(17), 2289-2300.

https://doi.org/10.1016/1352-2310(95)00101-4

Kummer, U., Pacyna, E., \& Friederich, R. (2009). Assessment of heavy metal releases from the use phase of road transport en Europe. Atmospheric Environment, 43(3), 640-647.

https://doi.org/10.1016/j.atmosenv.2008.10.007

Lequy, E., Calvaruso, C., Conil, S., \& Turpault, M. P. (2014). Atmospheric particulate deposition influence by tree canopy in beech forests in the north of France. Science of the Total Environment, 487, 206-215.

https://doi.org/10.1016/j.scitotenv.2014.04.028

López-García, P., Gelado-Caballero, M. D., Santana-Castellano, D., Suarez de Tangil, M., Collado-Sanchez, C., \& Hernandez-Brito, J. J. (2013). A three-year time-series of dust deposition flux measurements in Gran Canaria, Spain: a comparison of wet and dry surface deposition samplers. Atmospheric Environment, 79, 689-694. https://doi.org/10.1016/j.atmosenv.2013.07.044

Lu, S., Shao, L., Wu, M., \& Jiao, Z. (2006). Mineralogical characterization of airborne individual particulates in Beijing PM10. Journal of Environmental Sciences, 18(2), 323-328.

Marx, S. K., \& McGowan, H. A. (2005). Dust transportation and deposition in a superhumid environment, West Coast, South Island, New Zealand. Catena, 59(2), 147-171. https://doi.org/10.1016/j.catena.2004.06.005

Mason, B. H. (1966). Principles of geochemistry ( $3^{\text {rd }}$ ed.). New York: Wiley and Sons.

Mucha, A. P., Vasconcelos, M. T. S. D., \& Bordalo, A. A. (2003). Macro benthic community in the Douro Estuary: relations with trace metals and natural sediment characteristics. Environmental Pollution, 121(2), 169-180. https://doi.org/10.1016/S0269-7491(02)00229-4 
Muhammad, I. K., Muhammad, I., Mubashir A., \& Ammad H. K. (2017). Geotechnical characteristics of effluent contaminated cohesive soils. Journal of Environmental Engineering and Landscape Management, 25(1), 75-82.

Niemiet, J., Tervahattu, H., Virkkula, A., Hillamo, R., Teinita, K., Koponen, I., \& Kulmala, M. (2005). Continental impact on marine boundary layer coarse particles over the Atlantic Ocean between Europe and Antarctica. Atmospheric Research, 75(4), 301-321. https://doi.org/10.1016/j.atmosres.2005.01.005

Orange, D., \& Gac, J. Y. (1990). Bilan géochimique des apports atmosphériques en domaines sahélien et soudano-guinéen d'Afrique de l'Ouest (bassins supérieurs du Sénégal et de la Gambie). Géodynamique (Paris), 5, 51-65.

Rodriguez, S., Querol, X., Alastuey, A., Kallos, G., \& Kakaliagou, O. (2001). Saharan dust contributions to PM10 and tsp level s in Southern and Eastern Spain. Atmospheric Environment, 35(14), 2433-2447. https://doi.org/10.1016/S1352-2310(00)00496-9

Saliba, N. A., Kouyoumdjian, H., \& Roumie, M. (2007). Effect of local and long-range transport emissions on the elemental composition of PM10 and PM2.5 in Beirut. Atmospheric Environment, 41(31), 6497-6509.

https://doi.org/10.1016/j.atmosenv.2007.04.032

Schiff, K. C., \& Weisberg, S. B. (1999). Iron as a reference element for determining trace metal enrichment in Southern California coast shelf sediments. Marine Environmental Research, 48(2), 161-176. https://doi.org/10.1016/S0141-1136(99)00033-1

Seinfeld, J. H., \& Pandis, S. N. (1998). Atmospheric chemistry and physics: From air pollution to climate change, (pp. 714-722). New York: John Wiley ans Sons. https://doi.org/10.1063/1.882420

Serbaji, M. M. (2000). Utilisation d'un SIG multi-sources pour la compréhension et la gestion intégrée de lécosystème côtier de la région de Sfax (Tunisie). Thèse de Doctorat de l'Université de Tunis II, Tunisie.

Serghani, N. (2009). Mesure de la pollution particulaire et métallique dans l'air au niveau de trios sites urbaines de la ville de Constantine. In Colloque International Environnement et Transports Dans des Contextes Différents (pp. 157-162), Ghardaia, Algerie, Février, E.N.P. Actes, Ed.

Shahin, U., Lu, J., Yi, S. M., Paode, R. D., \& Holsen, T. M. (2000). Long-term elemental dry deposition fluxes measured around Lake Michigan with an automated dry deposition sampler. Environmental Science \& Technology, 34(10), 1887-1892. https://doi.org/10.1021/es9907562

Shokr, M. S., El Baroudy, A. A., Fullen, M. A., El-Beshbeshy, T. R., Ali, R. R., Elhalim, A., Guerra, A. J. T. \& Jorge, M. C. O. (2016). Mapping of heavy metal contamination in alluvial soils of the Middle Nile Delta of Egypt. Journal of Environ- mental Engineering and Landscape Management, 24(3), 218231. https://doi.org/10.3846/16486897.2016.1184152

STATIT-CF. (1986). Services des études statistiques de l'I.T.C.F. Boigneville.

Tagorti, M. A., Essefi, E., Touir, J., Guellala, R., \& Yaich, C. (2013). Geochemical controls of groundwaters upwelling in saline environments: Case study the discharge playa of Sidi El Hani (Sahel, Tunisia). Journal of African Earth Sciences, 86, 1-9. https://doi.org/10.1016/j.jafrearsci.2013.05.004

Tagorti, M. A., Gam, W., Mathlouthi, W., Barka, S., Achour, L., \& Kacem, A. (2010). Etude des bioressources des tables salantes de la société Saida à sebkha Sidi El Hani. Première journée scientifique sur la valorisation des bioressources à intérêt alimentaire de GEDIV, Monastir le 08 mai 2010, Tunisie.

Terzi, E., \& Samara, C. (2005). Dry deposition of polycyclic aromatic hydrocarbons in urban and rural sites of Western Greece. Atmospheric Environment, 39(34), 6261-6270. https://doi.org/10.1016/j.atmosenv.2005.06.057

US EPA. (1999). SW-846 reference methodology: Method 3050 B. Standard operating procedure for the digestion of soil/sediment samples using a hotplate/beaker digestion technique. Chicago, IL.

Yang, H. H., Hsieh, L. T., Lin, M. C., Mi, H. H., \& Chen, P. C. (2004). Dry deposition of sulfate-containing particulate at the highway intersection coastal and suburban areas. Chemosphere, 54(3), 369-378. https://doi.org/10.1016/S0045-6535(03)00655-6

Yi, S. M., Totten, L. A., Thota, S., Yan, S., Offenberg, J. H., Eisenreich, S. J., Graney, J., \& Holsen, T. H. (2006). Atmospheric dry deposition of trace elements measured around the urban and industrially impacted NY-NJ harbour. Atmospheric Environment, 40(34), 6626-6637. https://doi.org/10.1016/j.atmosenv.2006.05.062

Zayed, J., Hong, B., \& Espérance, G. (1999). Characterization of Manganese-containing particles collected from the exhaust emissions of automobiles running with MMT additive. Environmental Science \& Technology, 33(19), 3341-3346. https://doi.org/10.1021/es990709+

Zhang, L., Xin, Y., Feng, H., Jing, Y., Ouyang, T., Yu, X., Liang, R., Gao, C., \& Chen, W. (2007). Heavy metal contamination in western Xiamen Bay sediments and its vicinity, China. Marine Pollution Bulletin, 54(7), 974-982. https://doi.org/10.1016/j.marpolbul.2007.02.010

Zhou, F., Guo, H., \& Hao, Z. (2007). Spatial distribution of heavy metals in Hong Kong's marine sediments and their human impacts: a GISbased chemometric approach. Marine Pollution Bulletin. 54(9), 1372-1384.

https://doi.org/10.1016/j.marpolbul.2007.05.017 